\title{
Aorden
}

\section{Agriculture and the environment in the Nordic countries}

Policies for sustainability and green growth

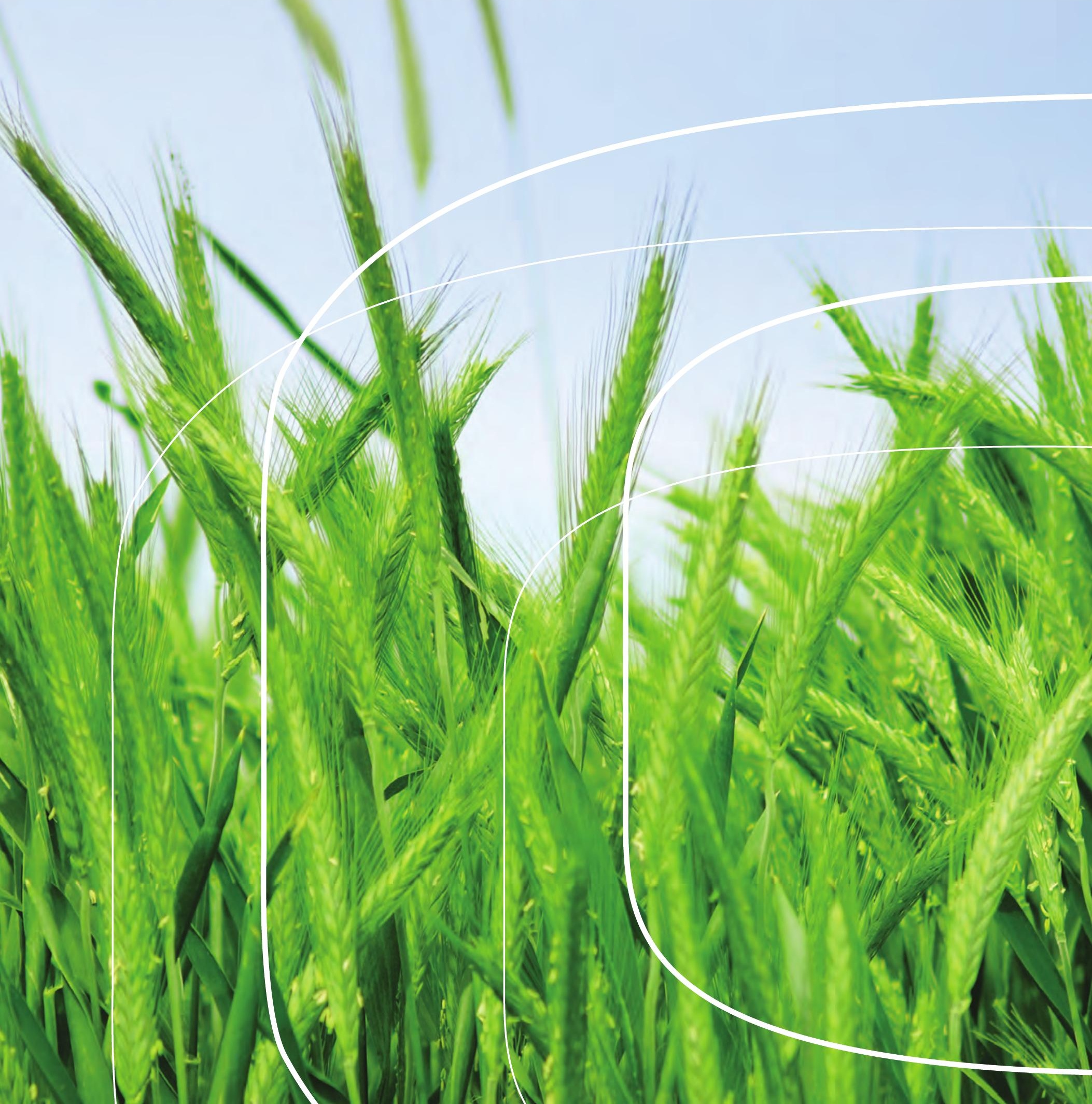



4 norden 



\section{Agriculture and the environment in the Nordic countries}

Policies for sustainability and green growth

Anne Strøm Prestvik, Valborg Kvakkestad and Øystein Skutevik

TemaNord 2013:558 
Agriculture and the environment in the Nordic countries

Policies for sustainability and green growth

Anne Strøm Prestvik, Valborg Kvakkestad and Øystein Skutevik

ISBN 978-92-893-2595-0

http://dx.doi.org/10.6027/TN2013-558

TemaNord 2013:558

(C) Nordic Council of Ministers 2013

Layout: Hanne Lebech

Cover photo: CStock.xchng.

This publication has been published with financial support by the Nordic Council of Ministers. However, the contents of this publication do not necessarily reflect the views, policies or recommendations of the Nordic Council of Ministers.

www.norden.org/en/publications

\section{Nordic co-operation}

Nordic co-operation is one of the world's most extensive forms of regional collaboration, involving Denmark, Finland, Iceland, Norway, Sweden, and the Faroe Islands, Greenland, and Åland.

Nordic co-operation has firm traditions in politics, the economy, and culture. It plays an important role in European and international collaboration, and aims at creating a strong Nordic community in a strong Europe.

Nordic co-operation seeks to safeguard Nordic and regional interests and principles in the global community. Common Nordic values help the region solidify its position as one of the world's most innovative and competitive.

\section{Nordic Council of Ministers}

Ved Stranden 18

DK-1061 Copenhagen K

Phone (+45) 33960200

\section{www.norden.org}




\section{Content}

Preface

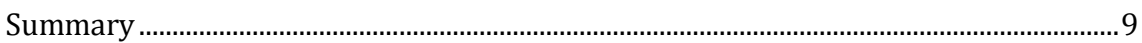

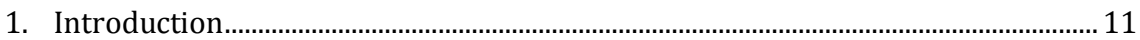

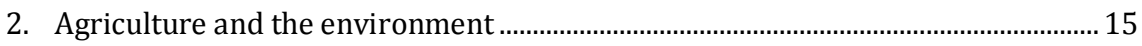

$2.1 \quad$ Nutrient runoff to water ................................................................................... 15

2.2 Greenhouse gas emissions from agriculture .................................................. 20

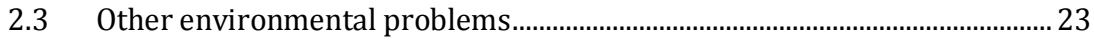

3. Multifunctional agriculture and farmer behaviour ................................................. 25

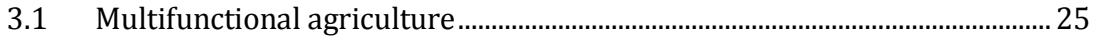

3.2 Farmer behaviour............................................................................................. 26

3.3 Policy implications of multifunctionality and observed farm

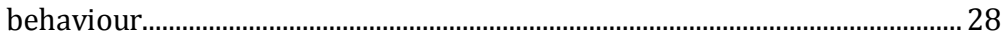

4. Agri-environmental policy instruments in the Nordic countries............................... 31

4.1 Agri-environmental policy in the Nordic EU-countries.................................. 31

4.2 Agri-environmental policy in Iceland............................................................... 37

4.3 Agri-environmental policy in Norway ……................................................... 37

4.4 Summary of Nordic agri-environmental policy instruments ........................ 38

5. Nordic experiences in agri-environmental policies ................................................ 41

5.1 The impact of agri-environmental policy in Finland on phosphorus and

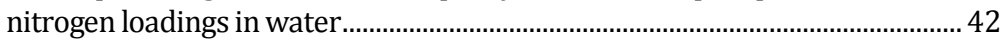

5.2 Sweden: Economics of eutrophication management ..................................... 50

5.3 Water protection policies and management in Norway................................... 57

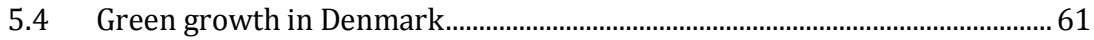

5.5 Soil conservation in Iceland .......................................................................... 68

5.6 Taxes and other policies for reducing greenhouse gas emissions

from agriculture............................................................................................... 71

5.7 The potential of biofuels for mitigating climate change and water quality............................................................................................................ 75

5.8 Summary of Nordic studies on policy measures for reduced

phosphorus and nitrogen loadings in water...................................................... 81

6. Policies for sustainable agriculture and green growth ............................................. 83

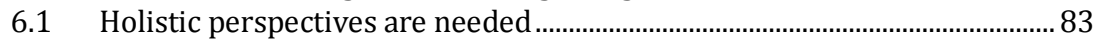

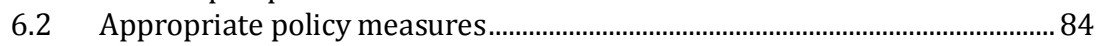

6.3 Appropriate point of instrument application ............................................. 85

6.4 Appropriate processes............................................................................................. 86

6.5 Lessons that could be important for green growth.......................................... 86

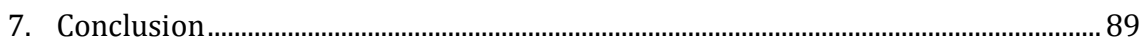

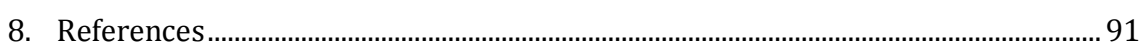

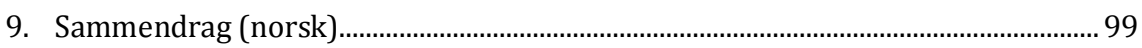





\section{Preface}

Agriculture delivers a combined set of private and public outputs like food products, landscape values, biodiversity and pollution. This is so because agricultural production is directly interlinked with the ecosystems it operates within and the space it utilizes. Inputs like land, water, air, fertilizers, pesticides, energy, etc., are combined in different processes. Out of this process come tradable private goods like grain and public goods and bads like landscape values, food security, pollution etc. A sustainable agriculture requires production processes that optimize on and balance environmental, social and economic outputs.

This report focuses on how agricultural policy measures, in particular payments and compensations to farmers, can be developed in order to support an environmental sustainable agricultural production and green growth. This is done by a literature review on Nordic studies. Important considerations when formulating policies for sustainable agriculture that are identified through this study includes precision, transaction costs and farm behaviour. Holistic perspectives, appropriate policy measures, appropriate point of instrument application and appropriate processes are needed to ensure a sustainable agriculture.

Economic instruments like taxes, subsides or tradable emission permits could be used to reduce water pollution for nitrogen and phosphorus and to reduce GHG emissions from agriculture. The report analyses how economic instruments could be applied to tradable input factors like fertilizers and feeds, to particular production methods or to foodproducts. Economic instruments could be used in combination with information and norm-building instruments. Participatory processes could be important for farmers response to these instruments. 
The report discusses different possibilities to approach the green growth concept in the case of agriculture. Green growth could be seen as a development where the economic value of agriculture grows without increasing food production. This could be achieved through increased production of services and value added products that receive a price premium due to specific production methods or locations.

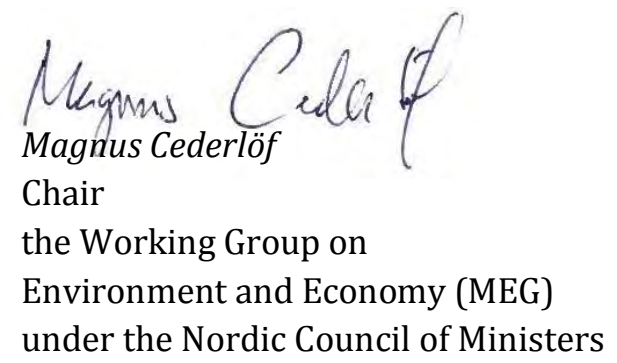




\section{Summary}

The purpose of this report has been to analyse how agricultural policy measures can be developed in order to support a sustainable agricultural production and green growth. The focus has been on payments and other economic incentives directed at farmers and on Nordic experience.

Nitrogen and phosphorus are important plant nutrients that can cause great harm it they enter water systems. Chapter two explains the processes where nutrients from agricultural soils enter water systems through leaching and erosion. Greenhouse gas emissions from the agricultural sector, carbon storage in agricultural soils and biodiversity on farms are also discussed.

Agricultural production and the surrounding terrestrial ecosystem are mutually dependent and forms closely integrated systems. Inputs like land, water, air, fertilizers, energy, etc., are combined in different processes. The output is tradable private goods like grain and public goods, and bads like landscape values, food security, pollution etc. Chapter three emphasises this combined output of private and public goods.

Agricultural policy-makers aiming for multifunctional agriculture often face a trade-off between transaction costs and precision. This is further complicated by farmer behaviour. Empirical studies show that farmers are not only motivated by economic incentives, but that their habits and norms also influence their behaviour and response to economic policy instruments.

In chapter four the agri-environmental policies in the Nordic countries are briefly described. The Nordic countries pursue many of the same goals for their agri-environmental policy. The policy instruments in Denmark, Sweden, Finland and Norway are similar in terms of a focus on several issues like cultural landscape, cultural heritage, biodiversity, greenhouse gas emissions, and nutrient (nitrogen and phosphorus) leakage, while the main focus on Iceland has been soil conservation.

Chapter five presents a selection of studies from the Nordic countries on agri-environmental policy instruments. Finland's agri-environmental program has a high participation rate but effects on water quality are considered insufficient and may even have been counterproductive in that it has given farmers incentives to cultivate more land. Analysis of alternative policies does not give a clear answer to what is more efficient 
for reducing nutrient losses to water. Decoupling support from production may, however, be more efficient.

In Sweden, agricultural measures to reduce nutrient loadings have proven somewhat successful, but reduction targets have not been met. Costs for reducing nutrient leakage further may be lowered if measures are applied where they have the lowest costs. Tradable emission permits may be a way to ensure this. Taxes on inputs like nitrogen in fertilisers, and output taxes such on e.g. meat have the potential to reduce greenhouse gas emissions significantly, but raise strong political opposition.

Denmark has successfully reduced $\mathrm{N}$ loading in water since the 1990 's by restricting fertiliser application and focusing on fertiliser efficiency. Further reduction is necessary to implement the Water Framework Directive, which implies high costs for the Danish agricultural sector. Biogas production from animal manure and other by-products have the potential to reduce nutrient losses to water and air, but will also require large investments.

The studies from Norway and Iceland show how farmers' knowledge and attitudes, in combination with the right economic incentives and management processes, can reduce erosion and land degradation.

Chapter six draws lessons from chapter five regarding how to formulate polices for a sustainable agriculture and green growth. It is emphasised that a holistic perspective that considers several policy goals and environmental problems simultaneously is needed, as well as appropriate policy instruments, appropriate point of instrument application and appropriate processes. It is important to acknowledge that farmers are not only motivated by economic incentives, but that habits, social recognition, and intrinsic motivation is important for them when they respond to policy instruments. It is also important to acknowledge that involving stakeholders in the process of developing and implementing policy-instruments is important for how farmers response to policies.

For green growth it is important to stimulate research, development, innovation, education, stakeholder communication and information to farmers. Good agricultural practises can increase the effecttiveness of nutrients and increase production without compromising the environment. The other side of the valuechain can contribute by reducing food waste and meat consumption. This could be achieved through economic instruments like food tax and/or trough changing habits and norms. Finally the production of bioenergy should be stimulated in order to achieve green growth in the society at large. 


\section{Introduction}

In June 2012 the Nordic Council of Ministers for fisheries, agriculture, food and forestry signed a declaration about the primary sectors' and food industry's responsibility for green growth. This declaration verifies the importance of the primary sector and food industry for green growth. The primary sector provides food, fibres, animal fodder, materials for construction and energy production. These products are of vital importance for the society. A growing global population requires increased food production. At the same time there is also increasing demand for energy and other non-food agricultural products. The aim of green growth is to increase both sustainability and competitiveness of production.

The last century has seen a large increase in agricultural production. Much of this increase is the result of increased use of inputs such as chemical fertilisers. This has not taken place without negative impact on the environment, in particular the aquatic environments that receive nutrient runoff and leaching from agricultural soils. In the 1960's and 70 's, the use of commercial fertilisers increased substantially in the Nordic countries. Later, the level has been reduced, but fertilisers are still considered the main cause of nutrient losses to water and air, causing eutrophication in freshwater and marine systems and incresing greenhouse gas emissions. In the future, the agricultural sector must both tackle increased demand for its products as well as the environmental challenges that are result from production. Climate change offers new challenges that can both increase the negative consequences of production, and change the conditions for agricultural production. Green growth is necessary, and depends on increased efficiency in all parts of the value chain, waste management, research and innovation.

The purpose of this report is to analyse how agricultural policy measures, in particular payments and compensations to farmers, can be developed in order to support a sustainable agricultural production and green growth. The report will focus on nutrient (nitrogen and phosphorus) losses from agricultural activities to water and air, but also touch upon other environmental problems and the production of public goods related to agriculture.

The report is mainly based on a literature review. The findings and data used in this report are collected from other studies considered to be 
relevant for agricultural and environmental policy in the Nordic countries. Researchers in the Nordic countries were asked to suggest literature they find relevant for the purpose. The response was good and some also suggested their own publications. Studies from other countries, especially studies covering new and innovative policy measures, are also covered when relevant.

The agricultural sector receives substantial subsidies, although the level of support has decreased in recent years. Focus has changed from supporting commodity production to also support the production of public goods like cultural landscapes and biodiversity, together with income. Policies that aim at reducing negative externalities, such as water pollution, are also developed. Multifunctional agriculture is a term that is often used to explain that agricultural production has multiple outputs. The multifunctionality of agriculture challenges policymaking because all outputs needs to be taken into consideration. Policy instruments targeted at one kind of output may negativelse impact other, less favorable outputs.

There are many potentially negative externalities from agricultural production. This report will focus on nutrient runoff to rivers, lakes and seas that causes eutrophication, and agricultures' contribution to greenhouse gas emissions. However, agricultural production, public goods and externalities are interlinked so that complete pollution removal is impossible.

That excess nutrients from agricultural production, in particular phosphorus and nitrogen, reduce water quality has been a concern for quite a while. These nutrients cause harm to the aquatic environment as well as reducing the social value of the water. Algae blooms and "dead" waters receive particular attention. According to an OECD report, agricultures negative impact on water quality is either stable or deteriorating (OECDb 2012). However, significant improvement has been observed, as will be presented in studies from the Nordic countries.

The agricultural sector's contribution to greenhouse gas emissions is increasingly recognised and the demand for this sector to take its share of reducing emission increases. Worldwide, agriculture accounts for $60 \%$ of nitrous oxide and $50 \%$ of methane emissions (Smith et al. 2007). However, agricultural production and soils can also store large amounts of $\mathrm{CO} 2$.

The EU countries in particular are constrained by a number of directives, e.g. the Nitrates Directive, that demand regulations on agricultural activities. All Nordic countries are implementing the Water Framework Directive and need to find efficient policies that will improve water quality. This report will focus on economic policy instruments as these will 
have to be developed within existing regulatory frameworks. Farmer behaviour and intrinsic motivation will also be discussed.

The report is organised as follows: Chapter 2 elaborates on the negative externalities that are the focus of this report; nutrient runoff to water and greenhouse gas emissions. It also briefly mentions other negative effects from agriculture. Chapter 3 presents characteristics of agriculture and farmers that are important when formulating policies for sustainable agriculture. Chapter 4 presents main agri-environmental policies in the Nordic countries. In chapter 5, relevant and interesting studies from Nordic countries are presented. Chapter 6 draws on the lessons from the studies presented in chapter 5 and, finally, chapter 7 concludes. 



\section{Agriculture and the environment}

Agriculture is based on natural resources and affects these in various ways. Some are direct, i.e. changes in eco systems as a result of agricultural production. Other consequences are less direct and may emerge away from the agricultural area, for example water pollution. Increased food production for a growing global population is intensifying the negative environmental impacts of agriculture; one of the gravest is water pollution that leads to eutrophication.

\subsection{Nutrient runoff to water}

The two most important nutrients for plant growth are phosphorus (P) and nitrogen $(\mathrm{N})$. Together with potassium $(\mathrm{K})$, these nutrients are called the primary macro nutrients because plants use large amounts of these for growth. Plants absorb these nutrients from the soil and most agricultural practises include adding nutrients to the soil to enhance plant growth. Nutrients can be added using chemical and organic fertilizers. Chemical fertilizers are fully or partially synthetic material rich in the three essential nutrients Nitrogen, kalium and phosphate (N-K-P). Organic fertilizers are commonly manure or other substances from remains or by-products of organisms.

Both $\mathrm{N}$ and $\mathrm{P}$ can find ways from the soil to water. These are essential nutrients for aquatic organisms and under normal conditions in scarce supply. Excessive supply of nutrients to water can lead to algal and bacterial blooms which disturb the ecosystems. Some forms of N, nitrates, are also harmful to humans and animals and can reach groundwater systems. $\mathrm{N}$ applied to the soil can also leach to air in a form that makes it a potent greenhouse gas.

There are many factors that affect the rate of which nutrients leach into water and air. Especially nutrients that are water soluble, like nitrate, move with drainage water and end up in rivers, lakes and the sea. This is enhanced when extra nutrients are applied with fertilizers. 


\subsubsection{Nitrogen}

Nitrogen gas $\left(\mathrm{N}_{2}\right)$ amounts to almost $80 \%$ of the air we breathe. Molecular nitrogen is extremely stable and difficult to convert into usable components for both organisms and industry. Certain bacteria can transform, or "fix", $\mathrm{N}_{2}$ into usable compounds for plants such as ammonia $\left(\mathrm{NH}_{3}\right)$. Ammonia is also industrially produced and can be used as a fertilizer directly or as a synthesis of nitrated fertilizers. Plants can only use specific inorganic forms of nitrogen, mainly ammonium $\left(\mathrm{NH}_{4}+\right)$ and nitrate $\left(\mathrm{NO}_{3}-\right)$. Ammonia and other chemically produced fertilizers like ammonium nitrate and urea are easily transformed into ammonium and nitrate, which plants can absorb and use. While ammonium is easily bound to soil particles, nitrate is free to leach from the soil, either with water or to air through denitrification. Ammonium is transformed to nitrates by bacteria in the soil in a process called nitrification. This transformation happens rapidly at higher temperatures. Denitrification is also a bacterial process where nitrate is reduced to $\mathrm{N}_{2}$ through several stages, one of which is nitrous oxide $\left(\mathrm{N}_{2} \mathrm{O}\right)$.

Nitrate that is not absorbed by plants may be transported by excess water below the root zone and end up in ground or surface water. The capacity of the soil to contain water [holding capacity of the soil] strongly affects the rate of nitrate leaching, but nitrate may leach from any soil as rainfall or irrigation water moves through the root zone. Another source of nitrogen loss is volatilization in the form of ammonia. Nitrogen can also be lost through soil erosion and runoff, which is more common for phosphorus.

\subsubsection{Phosphorus}

Phosphorus is a mineral that in its elemental form is highly reactive and mainly found as inorganic phosphate rocks. Weathering of phosphate rich rocks and minerals releases a very small amount of $\mathrm{P}$ in a form that can be used by plants. For use in chemical fertilizers, phosphate rock is dissolved with nitric acid to produce phosphate and calcium nitrate.

In soils $\mathrm{P}$ appear as a negatively charged phosphate ion which easily binds with other minerals. This makes phosphate tightly bound, adsorbed, to soil clay and organic matter. Plants can only take up P in the form of orthophosphate which is dissolved in the soil solution. Only a small fraction of total P content is in the dissolved form and available to plants. As plants grow and absorb the soluble P, the soils' small pool of dissolved $\mathrm{P}$ is replenished by inorganic phosphate bound to soil particles and decomposing organic materials. The soils' ability to provide soluble 
phosphate from adsorbed phosphate for plant growth is what makes it fertile in terms of phosphorus.

Decay of dead organic matter also releases $\mathrm{P}$ for plants through bacterial processes. By harvesting crops, $\mathrm{P}$ in plants is removed from the system and may over time deplete $\mathrm{P}$ in the soil. As $\mathrm{P}$ can be a serious constraint for plant growth, it is commonly added through manure and other organic and chemical fertilizers. The phosphate in fertilizers is generally highly available for plants, but quickly becomes bound to soil particles and other minerals. Over time the adsorbed phosphate forms compunds which make it less available to plants. Continued application of more $P$ than the plants absorb will lead to $\mathrm{P}$ accumulation in the soil, much of which is fixed and unavailable. These processes are dependent on several factors like the texture and acidity of the soil. Fine-textured soils like clay can generally accumulate more $P$ than coarse-textured soils.

P loss from soils happens through soil erosion as particulate phosphate is washed away with water and leaching of dissolved phosphate. Soil erosion has received most attention as most $P$ is bound to soil particles. However, if $\mathrm{P}$ has accumulated in the soil, it will also have an increasing amount of soluble $\mathrm{P}$ which can leach to water. When soil particles reach water they may act as sources or sinks of soluble phosphate depending on the conditions in the water. Leaching of $\mathrm{P}$ is particularly relevant for soils with high water tables and which are saturated with $P$ (Mullins 2009). Even small amounts of dissolved P that becomes available to aquatic organisms can have detrimental effects on water quality.

\subsubsection{Sources of nutrient pollution}

There are large variations across countries and within countries on the sources of nutrient pollution. However, agriculture is often the main source of water pollution in many OECD countries (OECDb 2012). Growth and intensification of agricultural production can enhance water pollution from agriculture.

The sources of pollution of the aquatic environment are divided into point sources and diffuse sources. The point sources are stationary locations and can be sewage treatment plants, industry, fish farms and agricultural sources like manure yards. Point sources are relatively easy to identify, locate and regulate. The implementation EUs Urban Wastewater Treatment Directive has successfully reduced phosphorus pollution from wastewater in Europe the last 20 years (EEA 2012b).

Pollution from diffuse sources cannot be located from a particular, but rather a large area and may come from several activities. Diffuse 
sources of $\mathrm{P}$ and $\mathrm{N}$ are mainly runoff water and eroded sediment from soils and atmospheric depositions. It includes background losses from natural areas and rural populations without wastewater treatment, but agriculture is the largest humanly generated diffuse nutrient source. In the Baltic Sea, for example, diffuse inputs constitute the largest nitrogen loading and agriculture contributed about $80 \%$ of the total diffuse loading to the sea (HELCOM 2009). For Finland and Sweden, agriculture is also the greatest contributor to phosphorus in the Baltic Sea (ibid.).

The EEA estimates that diffuse pollution from agriculture, especially in areas of intensive production, is the major threat to more than $40 \%$ of Europe's water bodies and rivers and coastal waters, and in one third of water bodies in lakes (EEA 2012a).

\subsubsection{Determinants of agricultural nutrient loadings}

Nutrients can enter water courses through surface runoff, soil leaching and atmospheric depositions. Runoff from rainfall, melting snow and irrigation can transport nutrients on the soil surface, both as dissolved and particular nutrients. Sub-surface drainage can also transport dissolved and adsorbed nutrients particles to water courses. Water can also transport nutrients through sinkholes, pourus or fractured rock directly into the groundwater. Leaching is the movement of dissolved nutrients through the soil.

A study by Vagstad et al. (2001) discussed the possible explanations for differences in nutrient losses in catchments in the Nordic and Baltic countries. It was based on the monitoring of nutrient concentrations in selected catchments in Nordic (except Iceland) and Baltic countries from around 1990 to 2000. Much has changed since then and the determinants for $\mathrm{N}$ and $\mathrm{P}$ concentrations in streams may be different now. The findings are cited here to illustrate the many factors that influence nutrient losses from agricultural soils. Main explanations for differences were water runoff, fertiliser use, particularly the use of manure, soil type and erosion risk. Hydrological processes, i.e. how the water moves (slow vs. fast), may explain differences in nutrient losses in similar soil types (ibid.). Agricultural practices such as crop rotations, nutrient inputs, and soil conservation measures play a significant role in determining nutrient losses. However, understanding of the interaction between basic characteristics of the catchments and agricultural practises is necessary to efficiently manage diffuse losses of nutrients from agricultural soils.

Soil type, agricultural production practises including fertilization, precipitation and water discharges were important determinants for 
nitrogen losses in agricultural catchments in Norway (Vagstad et al., 2001). Risk of erosion is higher with sloping lands, which is an important determinant for phosphorus losses.

In Denmark, the study by Vagstad et al. (2001) found that denitrification during groundwater transport can explain why $\mathrm{N}$ losses from sandy soils were lower than losses from loamy soil. Catchments where animal manure was the main fertiliser input experienced the highest $\mathrm{N}$ and $\mathrm{P}$ concentrations in the streams. The main determinant for $\mathrm{N}$ and $\mathrm{P}$ concentrations in streams seemed to be type of agricultural production.

In Sweden, the highest $\mathrm{N}$ concentrations were measured in catchments with intensive cropping systems, high $\mathrm{N}$ surplus in the soil and high water discharges. Phosphorus losses were related to high clay content in the soil which gives high risks of erosion, especially with high water discharges. The findings were similar in Finland.

\subsubsection{Nitrate in groundwater}

The rate of nitrate leaching depends on the hydro-geological conditions and there may be delay of nitrate transfer from the soil to the ground water varying from 2-3 years in sandy soils and up to 40 years in chalk limestone (EEA, 2005). If nitrates reach groundwater that is used as a source of drinking water for humans and animals, it may pose a serious threat to health. Among other health hazards nitrates in drinking water is believed to cause cancer and in rare occasions infant methaemoglobinaemia (blue baby syndrome) (OECD 2012b). Denmark depends on groundwater for drinking water supply and monitors the nitrate contents in the groundwater closely. Many shallow aquifers suffer from pollution, especially from nitrates and pesticides and cannot be used as source for drinking water (Danish Ministry of Environment).

\subsubsection{Eutrophication in freshwater and the sea}

$\mathrm{N}$ and $\mathrm{P}$ are naturally scarce in aquatic environment but vital for the aquatic organisms. When extra nitrate and phosphate enter freshwater and coastal water systems, the ecosystem may respond by sometimes dramatic changes that deteriorate water quality. Phosphorus is usually a limiting factor in freshwater systems and when extra is supplied, it enhances the growth of aquatic plants and algae. When algae and other organic materials die they sink to the bottom and are decomposed by bacteria, a process that uses oxygen and may result in the death of other organisms that also use oxygen in the water. Algal blooms disturb the 
natural ecosystem in a negative way and the water typically becomes cloudy and colored and even toxic for humans and animals. When eutrophication leads to a reduction in oxygen, fish and other organisms that becomes oxygen deprived die and the water becomes hypoxic. Hypoxia is the most severe symptom of eutrophication and severely affects the ecosystem, including making the water system unfit for recreational use (OECD 2012b).

In marine waters, nitrogen is commonly the limiting factor and increased levels can lead to eutrophication also in salt water. Hypoxia has been found more and more frequently in the Baltic Sees over the past five decades (Zillèn et al. 2008). This result in real economic losses for the communities surrounding the Baltic Sea which provides ecosystem services such as maintenance of fish stocks and human recreation.

\subsubsection{Water pollution and climate change}

Changes in climate and climate variability will affect locations of crop production, livestock production, technologies and management of agricultural production (OECD 2012b). Indirect consequences are the effects on water pollution from these changes in agricultural production. There are many factors that will determine how nutrient runoff and leaching will change but some that point in the direction of an increase. Higher temperatures, more rainfall and extreme weather events will increase bioavailability of nutrients, erosion and leaching. Climate change will probably make water quality targets harder to achieve in the future (ibid.).

\subsection{Greenhouse gas emissions from agriculture}

Agriculture is the producer of two powerful greenhouse gases (GHGs): Nitrous dioxide $-\mathrm{N}_{2} \mathrm{O}$ and Methane $-\mathrm{CH}_{4}$. The efficiency of these two gases compared to $\mathrm{CO}_{2}$ varies depending on which time horizon is used. A much used conversion for a 100-year timeframe gives $\mathrm{CH}_{4}$ and $\mathrm{N}_{2} \mathrm{O}$ a factor of 25 and 310 respectively in efficiency as a greenhouse gas compared to $\mathrm{CO}_{2}$.

According to the European commission the agriculture's share of the total greenhouse gas emissions in the EU, is about $9 \%$. This share has been reduced by $20 \%$ from 1995 to 2005, mainly due to changes in agricultural practises and reduced livestock (European Commission 2008). How much agriculture contributes to total emissions varies between countries. In Denmark the agricultural share is about $15 \%$, and in Nor- 
way it is about $9 \%$, close to the average in EU. In EU, close to $60 \%$ of the GHG emissions from agriculture is nitrous oxide, the rest is mainly methane. A small part of the $\mathrm{N}_{2} \mathrm{O}$ emissions are from manure storage, but between $80-90 \%$ of the $\mathrm{N}_{2} \mathrm{O}$ emissions are produced by the conversion of nitrogen in the soil.

\subsubsection{Nitrous oxide $\left(\mathrm{N}_{2} \mathrm{O}\right)$ from agriculture}

The main source of $\mathrm{N}_{2} \mathrm{O}$ emissions from agricultural soils is the use of natural manure and nitrogen fertilizers (EEAa, 2012). The $\mathrm{N}_{2} 0$ emissions are the result of two microbial processes in the soil; nitrification and denitrification. These processes are affected by soil moisture and temperature. Temperature determines the rate at which the soil microorganisms nitrify or denitrify; cooler temperature makes the process slower. The oxygen concentration is also important for the microbial processes that produce $\mathrm{N}_{2} \mathrm{O}$. It is influenced by the moisture concentration in the soil; high moisture increases the formation of $\mathrm{N}_{2} \mathrm{O}$ during nitrification and denitrification (IPNI, 2007). Under aerobic conditions the $\mathrm{N}_{2} \mathrm{O}$ emissions are at the lowest, while water clogged fields, such as rice fields, emit large amounts of $\mathrm{N}_{2} \mathrm{O}$.

Soil texture is another factor that is affecting $\mathrm{N}_{2} \mathrm{O}$ emissions. The physical properties of the soil determine the water filled pore space of the top soil (WFPS). WFPS above about 60\%, but below saturation, gives the greatest potential for $\mathrm{N}_{2} \mathrm{O}$ emissions (Granli and Bockman, 1994). That is the reason why soil compaction is a factor that stimulates $\mathrm{N}_{2} 0$ emissions. A study by Mosquera et al. (2007) shows that on average, $\mathrm{N}_{2} \mathrm{O}$ emissions were lowered by $20 \%$ when compaction was reduced, but emissions were doubled after heavy compaction. In general, soil with clay texture have the highest $\mathrm{N}_{2} \mathrm{O}$ emissions, and is the type of soil with highest risk of compaction from tillage implements and agricultural machines such as tractors. In sandy soils, the emissions were also lowered when compaction was reduced.

Increased nitrogen uptake in crops will also lower emissions of $\mathrm{N}_{2} 0$. All farming practices that increase the nutrient efficiency can decrease the need for fertilizers and at the same time lower $\mathrm{N}_{2} \mathrm{O}$ emissions.

\subsubsection{Methane $\left(\mathrm{CH}_{4}\right)$ emissions from agriculture}

Some of the methane emitted from agriculture comes from anaerobic decomposition processes in animal manure and waste products. The main part, however, is digestive processes in ruminant animals (enteric 
fermentation). In $\mathrm{EU}$, enteric $\mathrm{CH}_{4}$ contributed to more than $70 \%$ of the total $\mathrm{CH}_{4}$ emissions in 2005 (EC 2008). Hence the production of methane is closely related to livestock production, especially ruminants such as sheep and cattle.

Methane is produced in herbivores as a by-product of enteric formation, the digestive process where carbohydrates are broken down. The ruminant livestock are the major sources of methane emissions. Nonruminant livestock, such as pigs, have significantly less methane production. The methane production is positively related to the age and weight of the animal, the feed intake and the quality of the feed consumed.

The main driving force in the production of methane from enteric fermentation is the number of cattle and sheep. In EU-15, from 1990 to 2010, there was a decline in emission of $\mathrm{CH}_{4}$ from enteric fermentation by $11 \%$ from cattle, and $22 \%$ from sheep. The number of animals was reduced by $17 \%$ and $25 \%$ respectively. The trend is a decreasing number of animals, which leads to lower total $\mathrm{CH}_{4}$ emission. However, this effect is reduced by higher emissions per animal due to more intensive production (EEAa, 2012).

The production of methane from storage and management of animal manure comes from decomposition of the manure under anaerobic conditions. The highest emissions of methane occur when the manure is treated in liquid systems. Temperature and time of storage also influences the production rate of methane (EEAa, 2012). From 1990 to 2005, methane emissions from manure management were reduced by $9 \%$ in the EU (EC 2008).

\subsubsection{Carbon dioxide (CO2)}

Through photosynthesis, the plants consume large amounts of $\mathrm{CO}_{2}$ from the atmosphere. Some of this is converted back to $\mathrm{CO}_{2}$ when plants are consumed or decomposed, hence net uptake from the crop itself may be zero. Due to the large amounts of carbon that are cycled, the crops capture and store a significant amount of $\mathrm{CO}_{2}$. Some of it is converted to organic forms of carbon (C) that are stored in the soil (IPNI 2007). This way the soil can act as a $\mathrm{CO}_{2}$-sink, which can also release large amounts of $\mathrm{CO}_{2}$ under certain conditions. This mechanism is often not included in the overviews of agricultural greenhouse gas emissions although the agriculture is considered to have large potential to reduce $\mathrm{CO}_{2}$ content in the atmosphere by increasing carbon content in the soils (IPNI 2007).

There are some emissions of $\mathrm{CO}_{2}$ from the energy-use on the farm, but this is very small compared to the methane and nitrous oxide emis- 
sions (EC 2008). There are also some emissions from transport of agricultural products and manufacture of input factors, e.g. fertilizer.

Total greenhouse gas emissions from agriculture are influenced by management practices on the farm, but there are myriad interactions, so it is necessary to look at the farm as a whole to decide whether a measure is raising or lowering the farm's total GHG emissions (Bonesmo et al., 2012). For example, organic agriculture may lower emissions per hectare, but on a per-unit of output, the emissions may be higher (Stolze et al., 2000). Generally, efforts to maximise profit, which involves improving efficiency and lowering costs by increasing yields relative to input factors like fertilizers, pesticides, fuel etc., are expected to lower the GHG emissions per kg yield (Bonesmo et al., 2012)

\subsection{Other environmental problems}

\subsubsection{Soil degradation}

Soils are composed of different shares of mineral particles, organic matter, water, air and living organisms (EEA, 2010). Soil suitable for agricultural production and soil quality are exposed to many threats. It is affected by wind and water erosion. Use of heavy agricultural machinery can compact the soil. Salinization can make the soils unsuitable for plant growth. Contaminations like heavy metals and mineral oil are also reducing the soil fertility. Agricultural land is converted to housing or industrial areas. The soil biodiversity is also affected by the processes mentioned above. Landslides are also reducing the soil quantity available for agricultural production (EEA, 2010).

One important determinant for soil quality is the content of organic carbon in the soil (SOC), which is a primary constituent in soil organic matter (SOM). The soil acts as storage for carbon. In addition the SOM influences on the soil structure and stability, water retention, biodiversity and as a source of plant nutrients (EEA, 2010). Surplus nitrogen in the soil as a result of excessive use of manure, chemical fertilizer or low plant uptake, can increase the mineralization of carbon in soils, which in turn can release more carbon, and reduce the SOM content. Soils also loose organic content through conversion of grassland to arable land, deep ploughing, use of fertilizer and soil erosion. Much of these processes that leads to lower carbon content in soils are slow, and make changes difficult to assess. 
Erosion happens when soil or rock material is moved away from the agricultural land. The erosion can come from wind or water. Water erosion comes from rainfall, irrigation water or snowmelt, and is one of the most widespread forms of soil degradation in Europe (EEA, 2010). Generally northern Europe is less vulnerable to erosion than e.g. the Mediterranean region, due to less erosive rainfalls and more grassland. But arable land in northern Europe is also exposed to erosion, especially loamy soils without vegetation cover.

Compaction of the soil is normally divided into topsoil and subsoil compaction. Topsoil is the top 20-35 cm layer. Subsoil compaction is below this layer. Wheel traffic from heavy farm equipment is the main reason for soil compaction. If machines with axle loadings that exceed 10 tons are used, the risk of subsoil compaction is higher. This compaction is more difficult to remove with common implements. Compaction reduces the pore volume in the soil, resulting in less space for air and water. Some of the consequences are less nutrient uptake and plant growth, reduced water infiltration in the soil, and it increases the potential for runoff of nutrients and erosion, as well as $\mathrm{N}_{2} \mathrm{O}$ emissions.

\subsubsection{Agriculture, natural ecosystems and biodiversity}

Agricultural production influence natural ecosystems in many ways, from deforestation for making of new agricultural lands to pollution of nutrients and pesticides that can change ecosystems far away. Changing agricultural practises from extensive to intensive production alters the habitats of many species and is seen as a threat of biodiversity. Intensive production can reduce the biodiversity on farms when old and rare seed varieties and animal breeds are exchanged for new, high yielding varieties that may also have less genetic variation. Wild biodiversity is also reduced with more intense production. Landscapes become less diverse and fewer species finds habitats.

Agriculture both consumes and produces ecosystem services. Agricultural production depends on nutrient recycling and other processes in the soil and water. In addition to agricultural products, farms also provide habitats for many species, especially in the borders between agricultural fields and natural ecosystems. Many measures that reduce nutrient losses from agricultural soils also enhance farm and wild biodiversity, such as wetlands and riparian buffer zones. Finally, agricultural landscapes provide recreational value such as aesthetic scenery and cultural preservation. 


\section{Multifunctional agriculture and farmer behaviour}

In this section we first describe the basic characteristics of agriculture, namely the multifunctionality of agriculture. Next we describe characteristics of farmers in terms of their behaviour, and finally we elaborate on the policy implications of multifunctionality and observed farm behaviour.

\subsection{Multifunctional agriculture}

Multifunctional agriculture implies that agriculture delivers a combined set of private and public outputs like food products, landscape values and pollution. Agricultural production and the surrounding terrestrial ecosystem are mutually dependent and form a closely integrated system. Inputs like land, water, air, fertilizers, energy, etc., are combined in different processes. Outputs are tradable private goods like grain and public goods and bads like landscape values, food security, pollution etc. According to OECD (2001, p. 11) "Multifunctionality refers to the fact that an economic activity may have multiple outputs and, by virtue of this, may contribute to several societal objectives at once. Multifunctionality is thus an activity oriented concept that refers to specific properties of the production process and its multiple outputs" (OECD 2001). Multifunctionality may imply that private and public outputs are joint, complementary or competing (Kvakkestad and Vatn, 2004). If they are joint, inputs cannot be specifically assigned to individual outputs. A joint public is a consequence of producing a certain private good. Food security may have this characteristic. If they are complementary, the production of one good facilitates, simplifies the production of or enhances the value of a second good [contributes an element of production, which is joint with the first good and required in the making of the second good.] Cultural landscape may be of this type. Finally, we may have a situation where the private and public goods compete over some common factor of production. Some types of biodiversity and water quality may have these characteristics in the sense that they compete with agricultural production or forestry. 


\subsection{Farmer behaviour}

Recently, several studies have found that farm behaviour and farmers' intrinsic motivations are complex and influenced by the institutional context. Intrinsic motivations are important for determining how farmers respond to environmental policy instruments and could either complement or constrain the effect of policies (OECD, 2012a).

Several studies (e.g. Bergevoet et al. 2004; Gasson et al.1988; Gorton et al., 2008; Greiner and Gregg, 2011; Lien et al., 2006; Salamon, 1985; Willock et al., 1999) report that farmers have several goals and see farming as more than a way to make money. Lien et al. (2006) found that Norwegian farmers emphasise that the production of high quality food and sustainable and environmentally sound farming are more important than profit maximization. Gorton et al. (2008) found that non-pecuniary benefits of farming like quality of life, independence and lifestyle feature prominently in Europe. Gasson (1973) found that farmers have a predominantly intrinsic orientation to work, valuing the way of life, independence and performance of work tasks. Salamon (1985) found that farming strategies are selected within a context of ethnically derived family and farming goals, more complex than short-run profit optimization. Bergevoet et al. (2004) found that Dutch dairy farmers considered the joy of their work, producing a good and safe product and working with animals to be more important than maximizing profits. Greiner and Gregg (2011) fund that Australian farmers emphasise that passing on the land in good condition, looking after the environment and improving land conditions are more important than economic goals.

After the turn to multifunctional agriculture by the policy makers in the late 1990 's, a particular issue related to intrinsic motivation, namely farmers' emphasis on the production of food versus the production of public goods, has been examined by several authors. Rye and Storstad (2002) showed that Norwegian farmers found "providing consumers with safe food" and "maintaining competence with respect to food production" along with "to provide consumers with Norwegian food" important. Environmental objectives had a much lower score, except for "maintaining production area". Variables linked to viable rural communities and rural settlement all had relatively high scores. Burton and Wilson (2006) and Wilson (2001) emphasise that studies throughout Europe demonstrate that farmers' self-concepts are still heavily related to food-production. Burton and Wilson's (2006) study from Bedfordshire (UK) found that conservation is a relatively important part of the farmer self-concept although playing a subsidiary role to production- 
oriented identities. Davies and Hodge (2007) explored the diversity of UK farmers attitudes to environmental stewardship and found that no groups emerge with a purely productivist outlook, rather, it seemed that it was the interpretation of the 'conservation ethic'-how it is translated into practice, but not its fundamental legitimacy - that accounts for most diversity among farmers. Gorton et al. (2008) found that farmers (in five EU countries) find the production of food and fibres important, but so was also the production of landscapes and environmental goods.

Several authors have examined the influence of intrinsic motivation on the outcome of policy incentives. Breen et al. (2005) found that farmers' intentions to adjust to the agricultural policy instruments contrasted markedly with the predictions from a Linear Programming optimisation (LP-) model that assumed economically rational farmers. Battershill and Gilg (1997) found that the attitudinal dispositions of farmers were more important than their 'structural' constraints in influencing farmers' response to agricultural policy and Davies and Hodge (2006) found that attitudinal factors significantly determine the acceptability of cross compliance, and that structural and socio-demographic factors were considerably less important. Defrancesco et al. (2008) report that besides income factors, farmers' opinions on environmentally friendly practices have significant effects on adoption of agri-environmental measures. Greiner and Gregg (2011) found that motivational profiles explained differences in farmers' perceptions of and stated propensity to interact with policy instruments for conservation practices. Ryan et al. (2003) found that farmers who adopt conservation practices are intrinsically motivated rather than by receiving economic compensation. Siebert et al. (2006) reviewed publications on farmers' willingness to cooperate with biodiversity policies and found that financial compensation are an important, but not the only determining factor for farmers' decision-making. Vanslembrouck et al. (2002) found that environmental attitudes are significant determinants of the acceptance rate of agrienvironmental policies in Belgium. Economic factors were considered the primary reason for not taking part in country side stewardship measures by only $20 \%-30 \%$ of farmers. Most of these studies do, however, focus on attitudes towards agri-environmental instruments and not agricultural policy instruments in general. An important exception is, however, Gorton et al. (2008) who examined farmers' attitudes to different forms of payments in five EU countries. They find that farmers in these countries are about equally positive to payments for environmental good production, payments for commodity production and direct income payments and that farmers' attitudes to these different forms of 
payments depend on the nationality of the farm education, off-farm office work and whether located in a Less Favoured Area or not.

\subsection{Policy implications of multifunctionality and observed farm behaviour}

Given the economic perspective, optimal policies or precise policies demand equality between marginal costs and gains. Concerning costs, only marginal production costs are normally considered. Transaction costs on the other hand, are the costs for acquiring information, making contracts and controlling the deal. They are the costs of 'being precise'. By taking transaction costs into consideration, some of the standard conclusions obtained in the literature are altered and we often get a situation where there are trade-offs between transaction costs and precision (Vatn, 2002).

Vatn et al., (2002) developed principles concerning what should characterize an optimal policy for multifunctional agriculture when transaction costs are included in the analysis. If the private and the public goods are produced jointly, paying for the public good directly or via an increased price for the private good are equally precise - i.e., the resource allocation in the production of the goods will be the same. Transaction costs will, however, be much lower in the latter case since existing information from the market for the private good can be utilized. Contracting and controlling is also much easier.

Pure jointness - as above - may not be the typical case. In practice jointness between a private and public good may be what is called impure. These are situations where the public good is a function both of the production of the private good and some other inputs. Then, paying only via the private good will incur some loss of precision. Still, it may be more efficient to pay via the private good, maybe in combination with subsidizing this other input if it is traded. The conclusion depends on the case specific trade-off between transaction costs and the loss of precision.

If there is complementarity, the reasoning is parallel to the two prior cases. Complementarity implies that an input used in producing the public good is joint in production with the private one. As an example, agricultural fields are joint outputs with food production and an input into the creation of a landscape. If the production of the public good is based on inputs that are all joint with the private good, the policy conclusion is the same as for the situation with pure jointness. Paying via the private 
good is as precise as paying directly for the public good, while transaction costs are lower.

If other inputs are required for the production of the public good, we encounter the same trade off problem as in the case with impure public goods. To develop precise policy instruments, a case-by-case evaluation is necessary. The effect of the private good on the joint input may not be positive. It may create a public bad. Reduced water quality may be a joint output from food production. One example is nitrate pollution. Water may next be an input into the production of some landscape values, biodiversity etc. which become of lower quality. In this case corrections may be undertaken by reducing the price of the private good - e.g. by a tax on the food product. The conclusion is parallel to the reasoning above. If substitutes exist for the input that causes the damage - for example mineral fertilizers can be substituted by better utilization of ammonia in manure increasing the price of the polluting input may be more precise and thus preferable. Given that the input involved is traded, transaction costs should be low and of equal magnitude to that of the private good which is the alternative low cost point of instrument application. When the public and private good is competing over the use of the same resources, paying directly for the public good is the only relevant option.

A reasonable policy for multifunctional agriculture needs, however, also to consider actual farm behaviour. Above it is assumed that farmers will respond economically rational to economic incentives. Section 3.2 shows that farm behaviour is influenced by financial incentives as well as social norms and habits. OECD (2012) emphasise that the environmental outcome of policy instruments is usually much lower than their potential due to institutional, educational and social factors and that environmental improvements require a combination of economic policy instruments and other mechanisms, such as impacting habits, cognition and norms which can influence farmer behaviour. The attitudes and beliefs of farmers, as well as influence from local behavioural characteristics, must be taken into account when designing appropriate incentives. Economic policy instruments and incentives to farmers should therefore often be complemented with education, consultancy and communication while taking into account farmers' attitudes and beliefs. The point is not that economic incentives do not work, but that they often need to be combined with other instruments. 



\section{Agri-environmental policy instruments in the Nordic countries}

Policy instruments are normally divided into command-and-control instruments, economic instruments and information or norm building instruments. This chapter will mainly deal with economic policy instruments, but will also touch upon the other instruments. This chapter also gives an overview of policies related to environmental goals in the Nordic countries.

\subsection{Agri-environmental policy in the Nordic EU-countries}

\subsubsection{Current EU policies and cap reform}

In 2003, the Common Agricultural Policy (CAP) was subject to a fundamental reform, based on "decoupling" subsidies from particular crops. Member States do, however, have the choice to maintain a limited link between subsidy and production to avoid abandonment of particular production. The 2003 reform introduced the Single Farm Payment (SFP). This new scheme was intended to change the way the EU supported its farms by removing the link between subsidies and production of specific crops. The payments to farmers reflect historic patterns of production for different crops. The Single Payment Scheme (SPS) pays farmers for the land that they manage or own. Farmers can submit a claim for each year based on their land and their entitlements. Entitlements are the farmer's "right" to claim. In order to gain these rights, farmers had to make a successful claim during the first year of SPS or purchase them from another farmer. In order for farmers to qualify for payments under the scheme, they have to follow certain conditions and rules; their holdings must be at least 0.3 hectare and used for an agricultural activity; their land must be at their disposal for a period of ten months; they may have to set-aside a proportion of their land depending 
on their holding size and crops grown; and they must meet Cross Compliance standards that cover environment, food safety and animal health and welfare law (and good practices).

In addition to the direct subsidies, amounts are earmarked for rural development programs. The rural development program is divided into four areas, termed axes. Axis two covers management of natural resources. These amounts for rural areas and for special environmental considerations are paid on the premise that the individual countries themselves contribute a similar amount.

In 2011 a proposal for the new common agricultural policy 20142022 were presented. The proposal implied a greening of direct payments and new rural development policy for 2014-2020. The proposal contains the following instruments: (1) A basic payment scheme (flat rate per eligible hectare) where agricultural activity is required (keep animals, cultivate crops and/or maintain land in a condition suitable to be farmed without any preparation beyond traditional methods). (2) Green payments which imply that $30 \%$ of direct payments could be dedicated to practices which enable optimal use of natural resources like crop diversification, permanent grasslands and ecological focus areas. (3) Young farmer scheme. (4) Coupled support which implies support linked directly to the crops produced or livestock reared. These would only be permitted where the sector in question is undergoing difficulties and is particularly important for economic, social or environmental reasons. (5) Natural constraint support which imply an additional top-up payment per hectare for farmers whose land lies wholly or partly in "areas of natural constraint"

\subsubsection{The Danish rural development program}

One of the four objectives of the Danish Rural development program is rich nature and clean environment. Several of the impact indicators are related to water and greenhouse gas emissions:

- Improvement in water quality - reduction in nitrogen surplus

- Contribution to combating climate change - renewable energy

- Reduction in phosphorus emissions 
National requirements for farming practice and cross-compliance forms the basis for agri-environmental payments for measures implemented under the rural development program. The measures under the rural development program go beyond the nationally set baseline requirements. The basic requirements and the measures taken to implement the Nitrates Directive already restrict the farmers in terms of manure handling and spreading, livestock intensity, buffer zones, chemical fertilizer application and cover crops.

Measures under the rural development program are:

- Extensive farming

- Establishing and management of set-aside border strips

- Establishment and management of wetlands

- Conservation by grazing or cutting on pasture and natural areas

There are also specific support measures and agricultural practices related to water under the Article 68 program with special requirements. These measures are funded by unused funds under the EU's direct agricultural, a pillar 1 support. Article 68 allows EU states to retain by sector up to $10 \%$ of their national ceilings for direct payments. In Denmark this was DKK 178 million in 2012. One of the purposes these funds can be used for is protecting the environment. In Denmark these measures are:

- Extensive farming

- Establishment of perennial energy crops

- Management of permanent grassland

- Production of energy crops

- Establishment of organic fruit and berry production

As other agri-environmental measures fall under Pillar 2, article 68 can be seen as a way of greening the CAP and merging the two pillars (Hart and Baldock 2011). 


\subsubsection{The Swedish rural development program}

The overall objective of Sweden's rural development policy is to support the economically, ecologically and socially sustainable development of rural areas. One means of achieving this objective is the Rural Development Programme (The Ministry of Agriculture, 2010). Axis two in this program (management of natural resources), aims to achieve a sustainable development in agriculture, forestry and reindeer husbandry. The total budget for the program period of $2007-2013$ is $€ 3,9$ billion (http://europa.eu/rapid/press-release_MEM0-07-210_en.htm), in which almost $50 \%$ is from the EU and the rest is Swedish public funds. Axis two include compensatory allowance in less favourable areas, payments for environmentally friendly farming and payment for increasing biodiversity in forestry. Compensatory allowance are provided in areas where natural conditions for agriculture are less favorable, such as mountainous or forested areas, farmers may receive compensatory allowance to manage pastureland or for the cultivation of forage, grain or potatoes. This will serve to strengthen the regional economy and to promote an open and varied agricultural landscape (The Ministry of Agriculture, 2010).

The largest amount is used for environmentally friendly farming. Payments for environmentally friendly farming aims to contribute to agriculture that is better adapted to the environment and hence to the achievement of the Swedish environmental quality objectives (The Ministry of Agriculture, 2010). Payments are intended to maintain an open, varied agricultural landscape by cultivating forage, by managing seminatural grasslands and mown meadows or by preserving cultural heritage features in the agricultural landscape and reindeer husbandry area. Payments are also available for reducing plant nutrient leakage, reducing the risks of using chemical pesticides, and conducting organic forms of production. To preserve genetic variation, payments are also paid for keeping species of Swedish livestock that are threatened with extinction or cultivating traditional types of brown beans. A few specific types of environmental payments are only available in specifically designated areas of the country. 


\subsubsection{The Finnish Rural Development Program}

The total amount of funding for the Finnish rural development program was $€ 6.6$ billion for the six-year period, of which one third came from the EU. The largest share (81\%) of the RDP is allocated to axis 2 of which Measure 214, agri-environmental payments, gets 44\% (Berninger et al., 2011). The total funding for axis 2 totals about $€ 2.3$ billion (Niemi and Ahlsted, 2012). Axis 2 includes the agri-environment and natural handicap payments, non-productive investments and promoting the welfare of farm animals (Niemi and Ahlstedt, 2012).

Agri-environmental support was first introduced in 1995 and the current programme is the third agri-environmental programme. In 2007, the first year of the current program, the environmental support was $€ 315$ million. Payments have increased every year and were estimated to be $€$ 372 millions in 2011. In addition to agri-environmental payments, Finnish agriculture receive CAP support for arable crops and livestock, less favoured area (LFA) payments, national support to northern and southern Finland, national LFA and certain other national support.

The agri-environmental payments are meant to compensate for losses in income from reduced production output or extra production costs as the farmer commit to undertake certain measures. The main objective of the programme is to reduce nutrient loadings from agricultural lands to water. Most of the payments are directed to water protection measures while a small\% age of the payments are used for measures to enhance biodiversity (Niemi and Ahlsted, 2012). However, many of the water protection measures also enhance biodiversity, e.g. wetlands and riparian buffer zones.

The programme consists of basic, additional and special measures and payments vary according to region and measures undertaken (Aakkula et al., 2011) (box 1). Participation is extensive, in 2010 almost $90 \%$ of all farms in Finland, covering 92\% of total cultivated arable land, were committed to the basic measures. The basic measures are obligatory for participants in the program and concerns monitoring and planning of farm practices, fertilization of arable land, and headlands and filter strips (Berninger et al., 2011). Farms in southern parts of Finland (area A and B) must undertake between one and four additional measures while farms in northern parts (area C) can choose maximum two additional measures on a voluntary basis (Niemi and Ahlsted, 2012). The most popular additional measures are more accurate nitrogen fertilization, plant cover on arable lands during winter and calculation of nutrient balances (ibid.). 


\section{Box 1}

Water protection measures in the Finnish agri-environmental program

Basic measures:

- Environmental planning and monitoring.

- Fertilizer application to arable and horticultural crops according to soil fertility crop requirements.

- Reservation of wider headlands and broader set-aside margins along water channels.

Additional measures:

- $\quad$ Reduced fertilizer use.

- More accurate nitrogen fertilizer application on arable crops.

- Plant cover in winter.

- Reduced tilling.

- Extensive grassland production.

- Spreading of manure in growing season.

- Calculation of nutrient balances.

- Cultivation of catch crop.

Special measures:

- Establishment and management of riparian buffer zone.

- Management of multifunctional wetlands.

- Arable faming in groundwater areas.

- More efficient reduction of nutrient loadings.

- Runoff water treatment methods.

- Incorporation of liquid manure in the soil.

Source: Berninger et al., 2011.

To be compensated for basic and additional measures through payments, the farmer must comply with certain cross- and minimum requirements. The minimum requirements already include some maximum amount of nitrogen and phosphorus fertilizer use (Aakkula et.al, 2011). Special measures require additional contracts and are linked to special geographical areas. The payments for the special measures are 
linked to a particular area or number of animals while payments for basic and additional measures are paid for the farms' entire area. In 2009 the total agri-environmental payments to farmers were $€ 340$ million, € 220 million in compensation for basic measures, $€ 72$ million for additional measures and $€ 48$ million for special measures (Aakkula et.al, 2011).

\subsection{Agri-environmental policy in Iceland}

Iceland's natural conditions make the agricultural sector noncompetitive with other European countries (Jóhannesson 2010). Agriculture mainly consists of livestock production, dairy and sheep account for half of the production (OECD 2011a). Support to Icelandic farmers has been reduced by almost $30 \%$ from $1986-88$ to $2008-10$. The support consists of mainly price support which is sustained with border measures and quotas. Payments based on outputs are provided to dairy producers. In 1996, support to sheep meat producers changed from price support to direct payments based on historic entitlements. A regional scheme for sheep farmers implemented in 2008, also provide more decoupled payments. Agri-environmental policies focus on soil conservation and forestry through payments that aim to enhance sustainable land use and restoration of degraded land.

\subsection{Agri-environmental policy in Norway}

Sustainable agriculture is one of the policy goals for agriculture in Norway. More specifically they want to achieve protection of land resources, production of environmental goods, biodiversity, reduced climate emissions and water pollution (Ministry of agriculture and food, 2011). The most important agri-environmental subsidies include acreage and cultural landscape payments, payments for grazing livestock, support for preserving rare livestock breeds, support for organic farming, regional agri-environmental programs, payments for environmentally friendly spreading of manure, special environmental measures in agriculture and payments for selected cultural landscapes. From 1999, a differentiated environmental levy on pesticides has been in place. The fee is area-based and differentiated by the health and environmental risk of the pesticide. Pesticides are divided in seven tax classes depending on the health and environmental risks. 


\subsection{Summary of Nordic agri-environmental policy instruments}

Table 1 show that the Nordic countries hold many of the same goals for their agri-environmental policy. Denmark, Sweden and Norway are similar in terms that they focus on several issues like cultural landscapes heritage, biodiversity, greenhouse gas emissions, and nutrient (nitrogen and phosphorus) leakage, while Finland mainly focus on nutrient leakage and Iceland mainly focus on soil conservation.

Table 1 The main agri-environmental policy instruments in Norden

\begin{tabular}{|c|c|c|}
\hline Country & Environmental concerns & Main type of agri-environmental subsidies \\
\hline $\begin{array}{l}\text { Denmark. Rural } \\
\text { development } \\
\text { programme 2007- } \\
\text { 2013. Axis } 2\end{array}$ & $\begin{array}{l}\text { Rich nature and clean } \\
\text { environment }\end{array}$ & $\begin{array}{l}\text { Extensive farming } \\
\text { Biogas } \\
\text { Set-aside buffer zones } \\
\text { Energy crops } \\
\text { Maintaining wetlands } \\
\text { Rare livestock breeds } \\
\text { Municipal wet area projects } \\
\text { Environment Conditional grants } \\
\text { Environmentally friendly technologies } \\
\text { Nature and environment projects } \\
\text { Natura } 2000 \text { projects } \\
\text { Conversion to organic farming } \\
\text { Management of EB-grassland } \\
\text { Management of pasture and natural areas } \\
\text { Organic fruit trees and berry production } \\
\text { Island support }\end{array}$ \\
\hline $\begin{array}{l}\text { Sweden. Rural } \\
\text { development } \\
\text { programme 2007- } \\
\text { 2013. Axis } 2\end{array}$ & $\begin{array}{l}\text { Sustainable development } \\
\text { in agriculture }\end{array}$ & $\begin{array}{l}\text { Environmental Compensation for: } \\
\text { Pastures and hayfields } \\
\text { Forage cultivation } \\
\text { Certified organic or recycling-oriented production } \\
\text { Natural and cultural environments in the agricultural landscape } \\
\text { Reduced nitrate leaching } \\
\text { Brown beans on Öland } \\
\text { Endangered livestock breeds } \\
\text { Buffer zones } \\
\text { Environmental precautions } \\
\text { Natural promotion efforts on farmland } \\
\text { Compensation within designated environments (Pastures and hay } \\
\text { meadows, arable land, water, cultural heritage) }\end{array}$ \\
\hline $\begin{array}{l}\text { Finland. Rural } \\
\text { development } \\
\text { programme 2007- } \\
\text { 2013. Axis } 2\end{array}$ & $\begin{array}{l}\text { Reduce nutrient loadings } \\
\text { from agricultural lands to } \\
\text { - water. }\end{array}$ & $\begin{array}{l}\text { Basic measures: monitoring and planning of farm practices, fertili- } \\
\text { zation of arable land, and headlands and filter strips } \\
\text { Additional measures: reduced fertilizer use, more accurate nitro- } \\
\text { gen fertilization, plant cover in winter, reduced tillage, extensive } \\
\text { grassland production, spreading of manure in growing season, } \\
\text { calculation of nutrient balances, cultivation of catch crops. } \\
\text { Special measures: Establishment and management of riparian } \\
\text { buffer zone, management of multifunctional wetlands, arable } \\
\text { faming in groundwater areas, more efficient reduction of nutrient } \\
\text { loadings, runoff water treatment methods, and incorporation of } \\
\text { liquid manure in the soil }\end{array}$ \\
\hline
\end{tabular}




\begin{tabular}{ll} 
Norway $\quad$ Sustainable agriculture & Acerage and cultural landscape payments \\
& Payments for animals on pasture \\
& Support for preserving rare livestock breeds \\
& Support for organic farming \\
& Regional environmental programs (cultural landscapes, cultural \\
& heritage, biodiversity, recreational values, runoff to water, reduced \\
& use of pesticides.) \\
& Payments for environmentally friendly spreading of manure \\
& Special environmental measures in agriculture (cultural landscape, \\
& pollution and facilitation) \\
& Selected cultural landscapes \\
& \\
& Payments that aim to enhance sustainable land use and restora- \\
Iceland & tion of degraded land \\
\hline
\end{tabular}

Source: Ministeriet for Fødevarer, Landbrug og Fiskeri (2013), Jordbruksverket (2013), Niemi and Ahlsted (2012), Kvakkestad et al. (2012). 



\section{Nordic experiences in agri- environmental policies}

This chapter presents and discuss case- evaluations, alternative policy models and scenarios from the Nordic countries. Finland'sagrienvironmental program has achieved widespread participation. The program consists of payments to farmers who adopt measures that will reduce nutrient runoff to water and has been evaluated by many. Alternative policy instruments and further developments have also been suggested and will be presented in part 5.1.

Sweden has, along with other countries around the Baltic Sea, pledged to reduce its nutrient runoff to the sea. How Sweden and other countries plan to reach their reduction targets of nutrient runoff from agriculture in a cost-efficient manner is presented in part 5.2. Markedbased instrument like tradable quotas may be part of the solution and are also presented in this section.

In 2011, the part of Norway's regional agri-environmental program that relates to nutrient runoff, was evaluated. The most common measure in this program is reduced tillage in the autumn and the farmer was compensated. The estimated impact of this evaluation on runoff, the farmers' economy and the role of management and counselling is presented in part 5.3.

In Denmark, agriculture's pollution of soils, water and air is mainly due to intensive livestock production and the use of chemical fertilizers (OECD 2008). Nutrient efficiency is increasing, but agriculture still accounts for the greater part of nitrogen runoff. Denmark has a great focus on green growth in agriculture by enhancing the growth of energy crops and biogas from animal manure. How the policy instruments work and the impact on nutrient runoff to waterbodies and greenhouse gas emission is presented in part 5.4.

Iceland's natural resources are sensitive to human activities and especially livestock production has led to massive degradation of vegetation and soil erosion (Arnalds et al., 2001). How policy instruments and, more importantly, knowledge and awareness of soil erosion can turn the negative trends on Iceland is presented in part 5.5. 
Agricultural activities contribute to greenhouse gas emissions but can also contribute to reductions by storing carbon and producing input for biogas production. Policies for reducing greenhouse gas emissions are not as developed and researched as for water quality measures. Section 5.6 presents an evaluation of the impact of Swedish nitrogen tax on nitrous oxide emissions and how a tax on animal food can reduce GHG emissions from agriculture in Europe. Section 5.7 will present some policies for biogas production in Denmark and Sweden and evaluate potential for cultivating energy crops for biofuels in Europe.

\subsection{The impact of agri-environmental policy in Finland on phosphorus and nitrogen loadings in water}

The participation rate in the agri-environmental program may be seen as a measure of the program's effectiveness. However, participation is rather a measure of promised changes in agricultural practices and an indication that payments make participation relatively attractive compared to the costs (Laukkanen and Nauges, 2012). This section looks closer at the impact of the agri-environmental program on the environment and how it should be evaluated to understand its real costs and benefits.

\subsubsection{Impacts and evaluations of the Finnish agri- environmental program}

The legislation behind the agri-environmental programme requires evaluation and follow-up studies (Aakkula et al., 2011). One such followup study focuses on the impacts of the agri-environmental measures in the 2007-2013 programme (MYTVAS 3) and aims to evaluate how the measures have influenced the agricultural environment, preconditions for farm activities and suggest further development and improvement of the agri-environmental programme. The follow-up study finds that the measures with the greatest potential for reducing nutrient loadings are (reduced) fertilization of arable crops, set-aside margins/nature management fields and plant cover during winter (ibid.).

Changes in agricultural practices and structural changes in Finnish agriculture also have consequences for nutrient loadings and water pollution. The use of commercial fertilizers has decreased considerably in Finland since 1990 (Aakkula et al., 2011). The MYTVAS 3 and previous studies find that both nitrogen and phosphorus balances in the soil have decreased, mainly as a result of the reduction in fertilizer use. In recent 
years yield uptake of nutrients has increased in southern Finland, another important factor for reducing nutrient loadings to water. There has also been a change in land use from animal to cereal production and a tendency for intensification of animal husbandry in south-western and western parts of Finland.

Agricultural nutrient loadings in water were found to be decreasing for phosphorus and increasing for nitrogen between 1985 and 2006 (Aakkula et, al., 2011). Although the agri-environmental programme started in 1995 when Finland entered the EU, impacts may be small and hard to measure because of nutrient reserves in the soil, changes in agricultural production and even climate change (Ekholm et.al. 2007). Increase in nitrogen loadings may be a result of intensification in animal husbandry in certain areas as well as increase in field area (Aakkula et al., 2011).

Other studies of the agri-environmental programme in Finland have similar conclusions; although reductions in nutrient loadings have taken place, the effect of the agri-environmental program is not large. Laukkanen and Nauges (2012) emphasize that although farming practices have changed so that nutrient loadings are reduced, a multitude of factors influence farming practices and agri-environmental payments are only one of them. The effect of an agri-environmental program must therefore be evaluated in a larger context, preferably with other, alternative policy measures in mind.

Laukkanen and Nauges (2012) are particularly interested in the use of fertilizer and allocation of land to grain production and set-aside, which is considered key determinants of surface water pollution from agriculture. In order to include the other factors that influence farmer behaviour, they analyse an unbalanced panel from 1996 to 2005 of farms that have at least some of their land allocated to grain production in the three southernmost support regions in Finland. The data is based on a selection of individual Finnish farms for the period 1995 to 2005 (data collected for the European Commission's Farm Accountancy Data Network that contain physical and financial variables for agricultural production). Based on historical input and output prices, total land and agri-environmental payments and other subsidies, they model farmer decisions about fertilizer nutrient use and land allocation to grain production and set-aside land. The model is used to predict farmers' input use and land allocation to grain production, other production and setaside land, with and without the agri-environmental programme.

Farms that adopt special measures receive payments that cover investment and management costs up to a certain ceiling set by the EU. Over the study period, an increasing proportion of farms adopted such 
measures, rising from $12 \%$ in 1996 to $29 \%$ in 2005. Praticipation in the program is not random. Farmers' age has a statistically significant negative effect on participation, as younger farmers' may have a longer planning horizon, are better educated and willing to participate in the program. The price of labour, number of animals on the farm and farm size had a positive effect on participation. By taking land out of production for set-aside, riparian buffer zones or wetlands, labour requirements on the farm are reduced. Proximity to the West coast of Finland also has a positive effect on participation as farmers in this part are possibly more aware of the nutrient-related water quality problems in the Baltic Sea. Although participation in the agri-environmental is almost universal among Finnish farms, participation in the sub-program related to reduction of nutrient run-off is neither common nor evenly distributed.

Data on predicted land allocation, conservation measures like filter strips along water ways, and fertilizer use, was used in a nutrient pollution simulator to measure the environmental outcome of the agrienvironmental program. This was compared to a counterfactual scenario without an environmental policy, keeping the rest of CAP and prices constant. By comparing the counterfactual with the prevailing policy, it is possible to isolate the impact of the agri-environmental payments on farmer decisions and thereby nutrient loadings. They find that the payments result in minor reductions in fertilizer use, an increase in grain production area and a reduction in set-aside land. The latter is considered counter-productive as set-aside land has the potential to reduce nutrient runoff to water. Similar analysis from Germany and the United States suggest that participants in agri-environmental programs increase area under cultivation.

Although the program reduces fertilizer use, this effect is small, less than $2 \%$ reduction in fertilizer use. The reduction in fertilizer has resulted in a decrease in nutrient loadings from grain production by $8 \%$. Land changes that are part of the program, such as construction of riparian buffer strips, adds another $\%$ in reduction.

The estimated effect of the agri-environmental program was a reduction in nitrogen loading by $11 \%$ and phosphorus loading by $13 \%$ relative to what the counterfactual scenario with no agri-environmental payments. When this is combined with monetary measures for damage from nutrient runoff, the program reduced damage by $11-12 \%$ compared to the counterfactual case. When comparing these benefits from reduced damage with the costs of the payments, the cost-benefit ratio ranged from 0.68 to 1.05 depending on the calculation method. 
In conclusion, Laukkanen and Nauges state that the Finnish agrienvironmental program has reduced nutrient loading from agriculture, mainly by reducing fertiliser use. The reduction is not, however, large enough to meet Finland's water protection targets. More targeted policy instruments like fertilizer tax is suggested. The incentive created by the agri-environmental program to increase the grain area should also be changed. However, other benefits of the agri-environmental program, such as increases in biodiversity, reduced risk from use of pesticides and improved water quality in certain lakes in Finland, is not included in this analysis. Additional benefits such as increased biodiversity because of wetlands and reduced use of pesticides would increase the total benefits of the program. Locally, the FAEP may have had better results in certain lakes and waterways. Such benefits increase the total value of the program.

\subsubsection{Counterfactual scenarios and fertilizer constraints}

Lankoski and Ollikainen (2011) constructed a similar model of the impact of the Finnish agri- environmental programme and compared it to two counterfactual policy scenarios, (1) land use and allocation as in 1994 and (2) the CAP without agri-environmental payments. They developed a theoretical framework which was used for empirical analysis of farmer decisions on fertilizer intensity, land use and crops in the years 1995, 2001 and 2007. Based on these variables they estimate nutrient runoff using a model based on another study by Lankoski et al. (2006) which is based on Finnish data. In this model, phosphorus runoff is based on both easily soluble $\mathrm{P}$ in the soil and the rate of soil erosion and $\mathrm{P}$ content in eroded soil. Both nitrogen and phosphorus runoff for different crops and fallow land are estimated for the years 1995, 2001 and 2007.

In their analysis, Lankoski and Ollikainen separate the effects on nutrient runoff from several factors. These are:

- Total land under cultivation ,

- Allocation of land between crops, and

- The fertilizer constraint, which is part of the agri-environmental program.

Table 2 summarizes the effects.

Since Finland joined the EU in 1995 and the first agri-environmental payments were introduced the same year, land use and allocation between different crops has changed. From 1994 to 1995 there was a decrease in total agricultural land as a result of the changes in agricultural 
policy. Later, total cultivated area increased until it was almost on the 1995 level again in 2007. Before the first agri-environmental program, farmers were required to allocate a certain portion of their land to fallow (set-aside). Land allocated to fallow was reduced by half from 1994 to 1995 and was reduced further until 2007. In general, there was a shift to more fertilizer intensive crops and silage production from 1995 to 2001 and from 2001 to 2007.

Table 2. Nitrogen and phosphorus losses in actual and counterfactual scenarios

\begin{tabular}{|c|c|c|c|c|c|c|c|c|}
\hline & \multicolumn{2}{|c|}{1995} & \multicolumn{2}{|c|}{2001} & \multicolumn{2}{|c|}{2007} & \multicolumn{2}{|c|}{ 1995-2007 change } \\
\hline & $\mathbf{N}$ & $\mathbf{P}$ & $\mathbf{N}$ & $\mathbf{P}$ & $\mathbf{N}$ & $\mathbf{P}$ & $\mathbf{N}$ & $\mathbf{P}$ \\
\hline \multirow{2}{*}{$\begin{array}{l}\text { Actual (current } \\
\text { policy regime) } \\
\text { (tons) }\end{array}$} & 31,851 & 2,056 & 35,180 & 2,024 & 43,613 & 2,003 & 11,762 & -53 \\
\hline & \multicolumn{6}{|c|}{ Actual change in nutrient losses from 1995 to 2007} & $36.9 \%$ & $-2.6 \%$ \\
\hline $\begin{array}{l}\text { Relative change in } \\
\text { nutrient losses with } \\
\text { land allocation as in } \\
1995\end{array}$ & $0.0 \%$ & $0.0 \%$ & $-7.9 \%$ & $-4.2 \%$ & $-16.3 \%$ & $-8.5 \%$ & $14.7 \%$ & $-10.8 \%$ \\
\hline $\begin{array}{l}\text { Relative change in } \\
\text { nutrient losses with } \\
\text { land allocation as in } \\
1994\end{array}$ & $-8.8 \%$ & $-3.6 \%$ & $-16.1 \%$ & $-7.9 \%$ & $-24.5 \%$ & $-11.9 \%$ & $13.3 \%$ & $-11.0 \%$ \\
\hline $\begin{array}{l}\text { Relative change in } \\
\text { nutrient losses with } \\
\text { no fertilizer con- } \\
\text { straint and no land } \\
\text { allocation constraint }\end{array}$ & $10.4 \%$ & $-5.3 \%$ & $5.8 \%$ & $-6.4 \%$ & $6.1 \%$ & $-4.5 \%$ & $31.6 \%$ & $-1.8 \%$ \\
\hline
\end{tabular}

According to model estimates, nitrogen loading increased by $36.9 \%$. If land allocation was fixed as it was in 1995 or 1994, nitrogen loading would have increased by 14.7 and $13.3 \%$ respectively. Reductions in phosphorus runoff would have been larger, $10.8 \%$ with land allocation as in 1995 and $11.1 \%$ with land allocation fixed to 1994. In these two scenarios the agri-environmental program was included so that it is possible to isolate the effects of changes in land allocation. Changes in land allocation have led to a larger increase in nitrogen runoff and a smaller decrease in phosphorus runoff.

The agri-environmental programme set a limit to how much fertilizer the farmers can apply. Lankoski and Ollikainen (2011) estimated the optimal amount of fertilizer that would maximize farmers' profit based on market prices of inputs and outputs without the fertilizer constraint. For most crops the optimal amount of fertilizer was higher than the constraint. Between 2001 and 2007 the fertilizer application constraint in the agri-environmental programme was relaxed, i.e. participants were 
allowed to apply a larger amount of fertilizer. According to the model, nutrient runoff under the fertilizer constraint was larger in 2007 than in 2001 and 1995, a result of the relaxation of the fertilizer constraint. The application of phosphorus, on the other hand, has not resulted in increases in runoff and leaching. Both particulate and dissolved phosphorus runoff decreased during the same period because of the diminishing phosphorus content in the soil.

Without the fertilizer constraint, nitrogen losses would have been $10.4 \%$ higher in 1995. Later, the fertilizer constraint was relaxed and the preventive effect of the program was reduced. In 2001 and 2007 the program prevented 5.8 and $6.1 \%$ of the actual nitrogen runoff. Total increase in nitrogen runoff from 1995 to 2007 was smaller in\%age without the agri-environmental program, but higher in tons.

For phosphorus, however, the program has actually resulted in smaller reduction in nutrient loadings by on average 5.7\% from 1995 to 2007 when compared to the counterfactual. This can be explained by the increased area under cultivation during the program, which has outweighed the relaxation of the fertilizer constraint. Lankoski and Ollikainen (2011) conclude that the relaxed fertilizer application constraint and changes in land use contributed almost equally to the actual increase in nitrogen loading between 1995 and 2007.

This study has highlighted some interesting aspects of policy effects. The counterfactual scenario without the agri-environmental program suggests that nitrogen loadings would have been larger without the fertilizer constraint. However, another effect of the program is that the total area of cultivated land increased, possibly because the payments made it profitable for farmers to cultivate marginal land. This increase in total cultivated area has made phosphorus runoff reductions smaller than what was estimated under the counterfactual scenario with no agrienvironmental program.

Land allocation between crops has been as important for changes in nutrient runoff as the agri-environmental programme. The estimated nutrient loadings under the land allocation that existed in 1994 and 1995 were lower than the actual loadings. Since 1994-95 there has been shift to more fertilizer intensive crops and less fallow land. If land allocation had been kept as in 1995, the increase in nitrogen loading would have been $22 \%$ less and decrease in phosphorus loading four times more. In conclusion, the analysis by Lankoski and Ollikainen (2011) suggests that the agri-environmental programme has had positive impacts in that it has reduced nitrogen runoff compared to the alternative with no agri-environmental program. However, the program may also 
have impacts that counteract its own objectives, as well as the impacts of other policies and price changes.

Lankoski and Ollikainen (2011) conclude three effects:

1. Crop area and single farm payments give incentives to increase area under cultivation.

2. The combined effects of the crop area payments, single farm payments and relative prices leads to more land under cultivation and more fertilizer intense agriculture which both leads to increased use of fertilizer.

3. The agri-environmental payments may motivate farmers to utilize marginal land, a development that may increase nutrient runoff.

Potential counterproductive effects of agri-environmental payments need to be taken into consideration when agri-environmental programs are developed.

\subsubsection{Alternative policy scenarios for reduction in nutrient pollution}

Counterproductive effects of agri-environmental programs indicate that such payments and other policies that give farmers incentives to increase area under cultivation, should not be used to reach environmental goals. Removal of perverse support is argued to be an important policy change to decrease water pollution from agriculture (OECD 2012b). Analysis of alternative policy scenarios do not, however, give clear evidence that liberalisation will increase water quality. Lehtonen et al. (2005) found that full scale trade liberalisation would lead to a significant decrease in Finnish agricultural production. This reduction in production would not, however, lead to any additional environmental benefits in terms of reduced nutrient balances. The reason for this was that relatively competitive regions for dairy production in Finland would import feed grains which would result in increased nutrient balances in these regions.

Another study from Lehtonen et al. (2007b) also analysed alternative policy regimes and their implications on nutrient leaching on two catchments with varied environmental conditions and production. In the region with high yielding soil suitable for grains, nutrient leaching was quite stable across policy scenarios. Grain production in this region would be contained almost irrespective of agricultural policy. The other region, which was specialized in beef and dairy production, decoupling 
and decrease in beef and milk prices may result in extensive grass production and relatively large reduction in nutrient leaching. Under certain assumptions the model also shows that extensive cattle and grass production may lead to an increase in the soluble phosphorus leaching, which contradicts the notion that lower prices and decoupling always leads to a decrease in pollution.

Lehtonen et al (2007a) provides an economic sector level analysis of alternative national policies to reduce nutrient runoff from Finnish agriculture. With the EU CAP as it was in 2006 as the starting point, they investigated three different national policy strategies; a baseline scenario with small changes in output prices and the 2006 agri-environmental support scheme, a scenario with full decoupling from production of national support, partial decoupling of national support, a scheme of agrienvironmental payments for reducing both $\mathrm{N}$ and $\mathrm{P}$ surplus by $50 \%$ from the 1995 level, and finally a tax on $\mathrm{N}$ fertilizer which gives on average $20 \%$ tax rate. In the two last scenarios, all other support and prices are kept as in the baseline scenario.

None of the policy scenarios were superior in terms of reducing nutrient surplus. In the baseline scenario, set-aside area increased so that nutrient surplus decreased with approximately $10 \%$. Grain production decreased and livestock production decreased a little. On actively farmed land, phosphorus surplus would increase a little. Full decoupling of national support would also decrease nitrogen but especially phosphorus surplus and increase set-aside land more than in the baseline scenario. At the same time farm income would increase and like in the baseline scenario, phosphorus surplus would increase a little on actively farmed land. The scenario with payments for nutrient reduction is relatively effective for reducing nitrogen surplus, but also results in a negative income shock, a large increase in set-aside land, and reduction in pork and grain production. In this scenario, production is moved to the most productive regions and less productive regions have strong incentives to stop production. The tax on nitrogen, keeping national support coupled to production, results in $30-32 \%$ reduction in $\mathrm{N}$ and $\mathrm{P}$ surplus while keeping production volumes but has a negative impact on farm income. By taking into account the governmental expenses, the tax is nearly as effective as decoupling of national support in reaching reduction in nutrient surpluses.

In terms of reductions in nutrient surplus and farm income, full decoupling of national support is the most effective scenario in Lehtonen et al (2007a) analysis. However, by including the analysis done by Lehtonen et al. (2005), decoupling combined with trade liberalization, de- 
creases in support and/or decreases in grain prices, may lead to increases in nutrient balances, especially if meat prices remain high. Policy and price changes that give incentives for intensive livestock production will increase nutrient surpluses. Neither will decoupling alone ensure decrease in nutrient surplus in all regions since livestock intensity may increase in competitive regions. It should be mentioned that the results in this analysis depend on the cross-compliance requirement of keeping the land in good agricultural condition in order to receive support.

\subsection{Sweden: Economics of eutrophication management}

This chapter briefly presents Swedish efforts to reduce nutrient leaching to the Baltic Sea. The chapter draws heavily on a report by Katarina Elofsson (2010) to the Expert Group on Environmental studies. The objective of the report was to evaluate how nutrient-input permits trading can lower the costs of meeting the targets of Baltic Sea Action Plan. The notion of a nutrient trading scheme is in itself interesting, and the report concludes that the benefits of such a system may be substantial. The report also has a relevant focus on cost effectiveness and how differences in targets can change costs for achieving them. The focus of the report is not the agricultural sector alone. But when dealing with policies that reduce nutrient leaching from agriculture it will also be necessary to look to other sectors to improve cost efficiency.

Many of the Nordic countries are catchment areas to the Baltic Sea, a sea which has been reported to contain the largest anthropogenic "dead zone" in world. The countries surrounding the Baltic Sea have established the Convention on the protection of the Marine Environment of the Baltic Sea, working to reduce nutrient emissions to the sea to sustainable levels. The Convention includes quantified and targeted nutrient reductions for each Baltic Sea country (HELCOM Baltic Sea action plan 2007). In the Baltic Sea Action Plan (BSAP), Sweden has agreed to reduce phosphorus emissions into the Baltic Sea by 290 tons $(1.9 \%$ of total reduction target) and nitrogen emissions by 20,780 tons (15.6\% of total reduction target). Agriculture was the largest single contributor to both phosphorus and nitrogen loadings in 2006 (Ministry of Environment, Sweden 2010).

Nutrient runoff from agriculture is an important contributor to the eutrophication in the Baltic Sea. HELCOM countries have already achieved a $40 \%$ reduction in nitrogen and phosphorus discharges. But in 
order to reach the target of "clear water", phosphorus and nitrogen loadings must be further reduced 42 and 18\% respectively (HELCOM Baltic Sea action plan 2007). The Swedish Agency for Marine and Water Management has published a report that presents a number of studies that have modelled the costs of reducing the nutrients loadings in the Baltic Sea for all countries involved (Elofsson 2008). Agriculture as a sector is included in all of these studies as the potential to reduce nutrient runoff from this sector is great. The largest public, fiscal cost for reaching Sweden's targets is compensations through the Rural development program (Ministry of Environment, Sweden 2010). Low-cost measures for reducing nitrogen runoff from agriculture include wetland restoration, reduced fertilizer use and improved manure management. For phosphorus, only restoration of wetlands is related to the agricultural sector.

Trading in nutrient loading permits are a promising way of reducing the costs. According to Elofsson (2010), a basin-wide emission permit trading scheme can reduce total annual costs of reaching reduction targets by $€ 724$ million for the HELCOM countries. Bilateral cooperation, similar to the Clean development mechanism under the Kyoto protocol, can further reduce costs of cleaning the Baltic sea by including the countries that are not included in HELCOM (Belarus and Ukraine). Such schemes would insure that abatement is implemented where the costs are lowest.

Parts of Sweden's reduction targets have already been reached as both nitrogen and phosphorus discharges from agriculture to water have been reduced from 1995 to 2006 (Ministry of Environment, Sweden 2010). Changes in use of agricultural land and more efficient use of nutrients have resulted in an annual reduction in runoff from arable land with $12 \%$ nitrogen and $7 \%$ phosphorus. Other measures like establishment of wetlands, reduced soil cultivation and changes in crop cultivation have further reduced runoff by 870 tons nitrogen and 20 tons phosphorus (ibid.).

Through measures related to agriculture, Sweden plan to reduce nutrient loadings with 3,500-6,250 tons nitrogen and 40 tons phosphorus in the years between 2010 and 2016 (Ministry of Environment, Sweden 2010). However, the Baltic Sea can be divided into several drainage basins or catchments, which each have their own emission reduction targets. The basin-wide reduction targets increase the costs of reaching these targets because abatement must take place in specific watersheds where abatement may be more costly (Elofsson 2010).

Participation in the the agri-environmental support scheme in the Rural Development Program is voluntary. The Swedish Board of Agricul- 
ture works to educate farmers about nutrient losses in a program called "Focus on nutrients" (Elofsson 2010) and together with Swedish Farmers Association farmers are encouraged to adopt agricultural practices that reduce nutrient loss. An evaluation of the implemented measures to reduce leaching of nutrients from agricultural activities concludes that there are strong indications for achievement of their intended effect (Fölster et al. 2012). There has been a significant downwards trend in the concentration of both nitrogen and phosphorus in watercourses that are mainly agricultural. However, for phosphorus, the trend in reduction is only in the long term. In the short term, i.e. the last 10 years, there is no general trend.

There seems to be a positive relationship between the reductions in nutrient concentrations and the extent of measures implemented. In the Skagerrak and Kattegat Water districts in the south-western part of Sweden this relationship is particularly evident. The crop distribution has been changed in this area with an increase in grasslands and a decrease in spring crops. A database containing information on the distribution of crops, livestock density and implementation of environmental measures supports the notion that the measures have had an effect on reducing nutrient concentration in water. Catch crops in combination with spring cultivation could best explain the reduction of the concentration of inorganic nitrogen in water. A reduction in the area of spring crops could best explain reductions in the total concentration of phosphorus.

The education and advisory program "Focus on nutrients" gives farmers advice on how to reduce greenhouse gas emissions, nutrient surplus and safe use of pesticides (Fölster et al. 2012). The program covered $10 \%$ of the agricultural land in Sweden in 2010. Participation was highest in Skåne, southern Sweden, where $50 \%$ of the area was included in the program.

A report by Swedish Environmental Protection Agency (Naturvårdsverket 2008) concludes that many of the targets related to the national environmental objective "zero eutrophication" can be met. But no clear change in the state of eutrophication is visible since the last evaluation and the state of many lakes and streams are serious. The state of the Baltic Sea is considered the most severe with large algal blooms. The timescale for recovery is long, and there is hope that recent trends of falling nutrient concentrations, international initiatives like HELCOM and the EU Water Framework Directive will improve the environmental situation.

The Swedish Environmental Protection Agency suggests reduced tillage, a larger area and more permanent catch crops, a larger area of spring crops, set-aside land in especially sensitive areas, riparian buffer 
zones in along streams and lakes and other erosion prone areas, establishment of wetlands, build damns to trap phosphorus, lime filter drains, improved drainage and a decrease in phosphorus in livestock feed (Naturvårdsverket 2008). The most innovative measure is large scale mussel farming. Reduced tillage has the greatest potential in reducing nitrogen leaching, followed by wetlands, catch crops and spring crops. For phosphorus reduction, mussel farming has the greatest total reduction, followed by dams and buffer zones. In total, the suggested measures have the potential to reduce nitrogen leaching by 5,100 to 7,200 tons per year and phosphorus leaching by 236 tons per year at a cost between 4.1 and 4.6 billion per year. These numbers do, however, include significant uncertainties regarding the actual results.

\subsubsection{Cost effectiveness of nutrient reductions}

Elofsson (2010) developed a cost effectiveness model that includes abatement measures in the countries surrounding the Baltic Sea in order to analyse costs and effects of nutrient policies.

According to Elofsson (2010) there was disagreement between the Swedish EPA and the Swedish Board of Agriculture about the appropriate strategy as well as the costs of reducing nutrient leaching. However, the costs of reaching the target depend on not only measures, but on how the target is formulated. In the Baltic Sea Action Plan, targets are connected to catchments and reducing nutrient leaching from agriculture receives more weight. At the time of writing of Elofsson's report, Sweden had not yet adopted Baltic Sea Action Plan (BSAP) targets. Instead, targets agreed upon in the 1980's were the current nutrient targets. The total cost of agricultural measures under the BSAP is twice the total costs under the current targets. The reason for this difference is partly that the BSAP targets are higher. It is also because of the formulation of the BSAP targets which are spatially restricted to specific basins. This requires implementation of additional measures at higher abatement costs, thereby increasing the total costs.

In the BSAP, Sweden's targets are in three sea basins; the Baltic Proper, Danish Straits and Kattegat. All $N$ reduction targets are larger under the BSAP than the current targets. Phosphorus reduction is restricted only to the Baltic Proper basin under the BSAP, but reduction targets exists in all basins under the current targets. This also makes the BSAP target more expensive as more measures are required in the Baltic Proper region. Less expensive phosphorus reduction measures would have been implemented in other regions. There is evidence that phos- 
phorus loadings to other basins also affects the Baltic Proper basin through nutrient exchange (see e.g. Savchuk, 2003). Hence, costs of phosphorus reduction could be lowered by a more general phosphorus policy where reductions are made where costs are lowest. Current nutrient reduction targets are higher in the Danish Straits than under the BSAP. This difference reflects the large potential to reduce nitrogen loadings at a low cost in this catchment.

Measures that reduce both nitrogen and phosphorus leaching should be more attractive in implementation, especially if they are also cost effective. Cost-effectiveness also varies across regions. Riparian buffer strips are for example only cost effective in the catchment to the Bothnian Sea region according to Elofsson's model. Buffer strips are an expensive measure and would need additional benefits, e.g. biodiversity, to be economically defendable in other catchments. Reduction in livestock density is a cost effective measure in the Kattegat region while conversion to grassland is cost effective in northern catchments and the Baltic Proper. These measures simultaneously reduce $\mathrm{N}$ and $\mathrm{P}$ which gives them a cost advantage. The model also finds reduction in chemical fertilizer application to be a cost effective measure. In the model this measure account for $4 \%$ of nitrogen and $61 \%$ of phosphorus reduction. Marginal costs for phosphorus loading reduction in the catchments varied between EUR 3 and EUR 44 per kg P. Nitrogen loading reductions did not have a large variation in marginal abatement costs between catchments, approx. EUR 2 per $\mathrm{kg} \mathrm{N}$, a very low cost when abatement is only carried out where costs are lowest.

If the Swedish nutrient reduction policy had used the most cost efficient measures as estimated in the model, all BSAP targets could have been fulfilled by $65 \%$ using the same budget since 1995 . By reducing a small proportion of nitrogen abatement in the Baltic Proper region, a much higher amount of nitrogen abatement is possible in the Kattegat region with the same resources. If reduction targets under the BSAP are prioritized equally, i.e. phosphorus loading is reduced only in the Baltic Proper, marginal abatement cost would be EUR 48 per $\mathrm{kg} P$ in this basin. Marginal abatement costs for nitrogen would also vary, from EUR 30 per kg N in the Baltic Proper to EUR 8 per kg in $\mathrm{N}$ the Danish Straits. This means prioritizing the targets equally is economically optimal only if the benefit of reducing phosphorus loadings to the Baltic Proper by $1 \mathrm{~kg}$ is 6 times higher than reducing the nitrogen loading to the Danish Straits by $1 \mathrm{~kg}$.

Prioritizing measures that reduces one nutrient may also be economically viable as indicated by Boesch et al. (2006), who recommend focus in measures to reduce phosphorus loadings to the Baltic Sea. Measures 
to reduce nitrogen loadings are relatively expensive and focus on this nutrient only would not achievements much relative to reduction targets. By focusing in phosphorus only, this target can be met $100 \%$. Nitrogen reduction targets would be met by $55 \%$ because many of the measures that reduce phosphorus leaching also reduce nitrogen loadings. This would increase marginal abatement costs of phosphorus to EUR 1,390 per kg P, while marginal abatement costs of nitrogen would be EUR 8 per kg nitrogen in the Danish Straits. For this prioritization to economically optimal, the benefits of removing $1 \mathrm{~kg}$ of $\mathrm{P}$ to the Baltic Proper would be 170 times higher than removing $1 \mathrm{~kg}$ of nitrogen to the Danish Straits.

There is however, some disagreement on how prioritizing one nutrient will effect eutrophication. Boesch et al. (2006) argued that reducing phosphorus leaching should be the main concern for the open Baltic Sea, while reductions in nitrogen loadings would still be necessary, particularly sensitive areas of the Swedish east coast and the west coast. The Swedish EPA meant that the reduction targets for nitrogen were still important (EPA 2006).

\subsubsection{Market-based instruments - tradable emission permits}

In general, market-based policy instruments like environmental taxes and tradable emission permits will reach reduction targets more efficiently than command-and-control instruments like regulations (Elofsson 2010). Market-based instruments will ensure that abatement happens where it has least costs. Although command-and-control instrument may be more accurate in terms of achievements, market-based instruments are more flexible for the polluter. Moreover, a tax that makes it more costly to pollute, gives incentives for development of lowcost technologies to reduce emissions. A tax is seldom welcomed by polluters because of the increase in cost, while regulations and tradable emission permits might meet less resistance.

A tradable nutrient loading scheme for the HELCOM countries has been suggested by NEFCO (2008). A permit trading scheme can be established both between countries and within economies, as suggested by the Swedish EPA (2010). Countries or producers can be given permits according to historical emissions and can choose whether to meet targets by carrying out abatement or to buy or sell permits. Where abatement costs are low, reductions can be made further than the target and permits can 
be sold. Where abatement costs are higher than the market price of permit, expensive reduction can be avoided by buying extra permits.

Regional differences may need regionally differentiated policies for cost effectiveness. In general, measures undertaken closer to the sea has larger impact on the water quality in the sea. In Sweden, the RDP differentiates between regions and supports only farmers in the South for catch crops and spring crops. Stringent, uniform regulations may be cost-effective when abatement costs are low and impacts on water quality high. On the other hand, high cost measures with low impact should only be used if targets are very stringent and no other abatement options are available.

Ecological systems frequently offer uncertainty of the impacts of abatement as well as future abatement costs and benefits. When it is believed that marginal benefits of abatement decrease rapidly, while marginal abatement costs decrease slowly, a permit trading system may give the lowest efficiency losses. When marginal abatement costs increase rapidly while marginal benefits of abatement decrease slowly, a tax may be better. When there is no institution ready to collect a tax and ensure compliance, a permit trading system may have advantages.

Flexibility of the system must be weighed against transaction costs. Environmental taxes are commonly associated with lower costs than regulations. Permit trading schemes can also result in relatively high transaction costs, especially if this is not taken into consideration when the policy is designed. Analysis by the Swedish EPA (2010) show that transaction costs can be kept low in the short term for a permit fee system. The EPA would set up a permit fee system for large sewage treatment plants and forest industry enterprises. In the long term, it would be necessary to include additional sectors, among them agriculture. Finding the right cap for agriculture will require considerable research and development to fully understand the consequences of such a system.

There are few experiences from tradable permit schemes that involve the agricultural sector in Europe. In the United States water quality trading initiatives have increased in number since year 2000. A comprehensive survey from 2004 found more than 70 initiatives (Breetz et al. 2004). Despite efforts to develop trading programs, very little trading is taking place (King 2005). The conclusion may be that involving agriculture in point-nonpoint trading is hard to get started.

With the trading infrastructure in place, King (2005) suggests that it is the absence of willing buyers and sellers that prevent trading. Demand bare exists and does not provide positive prices. Tighter limits or caps in discharges need to be implemented and enforced for trade to take place. 
In some cases, because there is pressure to do something about water quality soon, taxes and subsidies are implemented and effectively eliminate all demand for water quality credits. The water quality trading programs also suffer from weak emission discharge restrictions, small and easily avoided penalties for non-compliance. King suggests that in order to create demand, non-compliance must cost more than buying permits.

In the US initiatives, agricultural non-point sources are believed to supply credits/permits. Farmers willingness to supply such credits may depend on several things; agricultural subsidies, green payments and expectations of future regulations. Farmers need to comply with baseline regulations in order to sell credits. This means that in order to sell credits, farmers must implement certain measures that go beyond what they are required to do. They also have to validate that the additional measures actually reduce nutrient leaching. Farmers may also be unwilling to reveal abatement costs on their property by selling credits to a certain price.

\subsection{Water protection policies and management in Norway}

\subsubsection{Reduced tillage and other measures to reduce phosphorus losses}

Norway's agri-environmental program consists of many subsidies paid to farmers who undertake certain practices or implement measures that reduce nutrient runoff to water. One part of the program is called "Runoff to water" and it was this part in particular that was evaluated in 2012 (Øygarden et al. 2012). The participation, impact and cost effectiveness was compared in 2006 and 2011 in 9 out of 19 counties in Norway. Since 2005, the agri-environmental program have been regional in nature, which means that county authorities can adjust measures to suit regional conditions like agricultural production, erosion risk and pollution level. Counties have the freedom to choose level of payments, adjust measures and implement new measures.

In $2010,56.3 \%$ of the area used for grain cultivation associated with minimum tillage. The measure "minimum tillage" comprises several tilling practises where the reference practise is ploughing in the fall after harvest. Minimum tillage then refers four practises; harrowing in fall, direct drilling of winter crops, no tillage in fall but ploughing or harrowing in spring and direct drilling in spring. The general measure was im- 
plemented on a larger area in 2010 than in 2006 in all but two counties. Implementation of other measures, riparian buffer zones, grass strips along streams and areas converted to permanent grassland, also increased from 2006 to 2010.

In Norway, cultivated area is classified according to erosion risk where category 4 has the highest risk. Measures like minimum tillage and conversion to grassland have the highest potential to reduce phosphorus losses when implemented on soils with the highest risks of erosion. In one county, minimum tillage in fall or conversion to grassland is implemented on all areas with erosion category 3 and 4 . In the other counties, the area in erosion category 3-4 that are ploughed in fall varies from 20 to 57\%. From 2006 to 2010, the area of minimum tillage in fall increased most in erosion category 1 and 2. Payments to farmers are differentiated according to erosion risk, but level of payment varies between counties. The evaluation found no evidence that differentiated payments caused increased implementation on areas with higher risk of erosion. Size of payment is only one of many factors that effects farmers' decision to implement measures.

A survey of farmers' attitudes and knowledge revealed that farmers demand counselling because of local variations when they decide what measures to implement (Refsgaard et al. 2010). Farmers' attitudes and knowledge may be an important factor in adopting minimum tillage practices as data show that it can be profitable for farmers to reduce phosphorus application. In catchments where focus has been on minimum tillage practices for several years, farmers' adoption rate of these practices is higher. This suggests that farmers' awareness of this practice affects the rate of adoption. Increased need of pesticides has been related to minimum tillage practices. That and other believed or real negative effects may also stop farmers from adopting such practices.

Some water catchments have additional requirements where $60 \%$ of total cultivated area should have no-tillage in fall, direct drilling of winter crops or permanent grassland. These requirements were fulfilled in 2010 which makes rate of implementation much higher in catchments with these requirements compared to other catchments in the same county.

These catchments have also implemented more measures like buffer zones, grass covered strips along streams and flood prone areas.

Estimated effect on erosion from the reduced tillage measures is 290,000 tons, which means a $9 \%$ increase in the total volume of reduced erosion (Øygarden et al. 2011). Net increases have been achieved in two counties because total area with no tillage in fall has increased. In another county net effect has increased despite reduction in total area with 
minimum tillage because such practices are implemented on a larger share of acreage with high risk of erosion. Reductions in erosion per unit of payment also varied across counties. When grass is established on land with high risk of erosion, the effect of the payment on reduced erosion is increasing. When measures are implemented on land with less risk of erosion, the effect of the payment can be negative because costs do not exceed the benefits of reduced erosion.

Cost related to changes in tillage practices was estimated as the change in farmers' gross margin as a result of the change. An analysis of farmers' gross margins with different tillage practices in two counties in Norway, found that changing from wither crops to spring crops with reduced tillage does reduce farmers' income (Refsgaard et al. 2010). However, there are significant variations in these costs. In some areas, the payment covers the costs, but not in all areas. The costs of reducing 1 kg of phosphorus ranged from NOK 2 000-3 000 on land with low erosion risk, to NOK 200-300 on land with great risk of erosion. Payments for reduced tillage in areas with low risk of erosion are not considered cost-efficient, i.e. loss in income for farmers exceeds the environmental benefit of reduced erosion.

According to the evaluation, there is still potential for reduced phosphorus leaching by reducing tillage on land with high risk of erosion. In particularly sensitive areas, additional measures may be necessary and the development of "packages" of measures that are suited for local conditions may be a natural extension of the agri-environmental payments.

The implementation of the Water Framework Directive will increase the need for local effective measures. Areas with high risk of erosion and/or that are particularly sensitive to eutrophication may need locally adjusted packages that contain several measures that are supported with payments to compensate farmers for extra costs or loss of income. At present, there is little coordination between measures under different programs that can potentially reduce nutrient losses, e.g. reduced tilling and fertilizer planning. In some areas, reductions in applied phosphorus and improved utilization of animal manure may be effective measures to reduce phosphorus surpluses. Reduction in applied fertilizer can also have other positive environmental effects like reduction in nitrous oxide emissions.

With climate change the need for measures to reduce nutrient leaching may be increasing, especially with increases in rainfall and higher temperatures that increases risk of erosion. The agricultural sector must adapt to climate changes and at the same time reduce GHG emissions and nutrient leaching. Agri-environmental program should include all environmental issues so that conflicting effects of measures does not arise. 


\subsubsection{Water governance}

When significant change in water quality is required, the governance of the catchment may be as important as measures and agri-environmental payments. The Lake Morsa in south-eastern Norway is an example of how local authorities can team up with stakeholders and return a lake to good ecological status, as is the aim of the WDF (Gunnarsdottir and Refsgaard 2012). The watershed included 9 municipalities in two counties and served as source of drinking water and recreational area for around 65,000 people. However, heavy loadings of phosphorus lead to eutrophication and toxic algae blooms. In 1999 the Morsa river basin organization was established and a process of creating trust and collaboration between the stakeholders were started.

The Morsa river basin based water management on knowledge, which led to public understanding and consensus. Objectives were based on analysis carried out by neutral institutes. Every municipality developed a plan for waste water treatment by 2002 and a partly regional and partly municipal environmental program for the agricultural sector came the same year and adopted by municipalities in 2003 .

The western part of the lake required special measures to reduce phosphorus loadings. All stakeholders, including farmers were invited to participate in creating an action plan. The solution was to apply environmental contracts between farmers and the county governor where payments were given to farmers who reduced phosphorus application on their fields and implemented other measures. $73 \%$ of farmers signed the contract and total use of phosphorus fertilizer was reduced by $75 \%$. No-tillage practices were adopted in the autumn, buffer zones were constructed along all streams and 16 wetland sediment traps were constructed. The process changed the farmers' attitudes and engagement in improving water quality.

The result was that the lake again became suitable for swimming in 2008. The result did not come without a cost. In total EUR 90 million were spent on measures, 20 million in the agricultural sector. The area of minimum autumn tillage was increased from 30 to $80 \%$ of the area, phosphorus fertilization was reduced by $50 \%$ and around 70 wetlands were constructed. However, good governance of the watershed that created trust, public understanding and collective action were critical factors for implementing the measures that resulted in significantly improved water quality in the lake and rivers. 


\subsection{Green growth in Denmark}

Danish agricultural policy is a combination of several types of policy instruments. The CAP provides direct subsidies through the single farm payment system and cross-compliance standards. The implementation of the Nitrates Directive provides further regulations regarding storage and spreading of slurry, application of nitrogen to the fields and catch crops. The Rural Development program and the Article 68 program provide agri-environmental payments for establishment and management of measures of particular environmental value. The implementation of the third Action Plan for the Aquatic Environment introduced a tax on phosphorus in animal feed. The following will present Denmark's experience with these policy instruments and the evaluation of alternative policy measures.

\subsubsection{Action Plans for the Aquatic Environment}

All of Denmark's agricultural land is classified as nitrate sensitive according EU's Nitrate Directive. The first Action Plan for the Aquatic Environment (APAE) from 1987 was one of the first initiatives to reduce nitrogen leakage. The second Action plan, implementing the Nitrates Directives in 1998, implemented further measures, including establishments of wetlands, limits on nitrogen fertilization, catch crops and afforestation. When it was evaluated in 2003, the already implemented as well as the measures that were about to be implemented were estimated to reduce nitrogen discharges by around 48\% since 1985 (EPA 2006).

From 1990 to 2003, the consumption of nitrogen in mineral fertilizer fell from 395 thousand tons to 196 thousand tons (Andersen et al., 2006). The application of nitrogen through manure was reduced from 244 thousand tons 237 thousand tons in the same period. These reductions in $\mathrm{N}$ application contributed to a decrease in total nitrogen surplus in field balance from 1990 to 2003 by 48\% (Jensen et al. 2012.). Part of this reduction is also a result of changes in land use, i.e. some arable land is no longer cultivated. A study that observed $\mathrm{N}$ concentrations in 86 streams which catchments were mainly arable land, found that for most streams the average annual $\mathrm{N}$-concentrations was below the target in the Nitrates Directive in the period 1989-2004 (Kronvang et al., 2008). Modelled nitrogen leaching within the same 86 catchments was on average reduced by $33 \%$.

The study by Kronvang et al. (2008) concludes that the APAE and other initiatives have shown that it is possible to reduce $\mathrm{N}$-leaching by a 
considerable amount while at the same time maintaining crop levels and increase livestock production. The reason for this has been the strong focus on nitrogen efficiency, combined with regulatory measures, intense research and an innovative farming community. Measures that increase nitrogen efficiency include improved utilization of animal manure, fertilizer and crop rotation plans, improved utilization of feed stuff and limitations on $\mathrm{N}$ application.

\subsubsection{Analysis of different policy instruments}

In preparation of the Action Plan for the Aquatic Environment (APAE) III, one of the three established working groups analysed a number of policy measures to reduce nutrient leakage (Arbejdsgruppen for generelle virkemidler, 2003). The analysis included economic instruments like taxes, quotas and subsidies as well as regulations. It also included the prospects of nutrient and "green" accounting, guidance and information to farmers and new technological developments. In the previous action plans, administrative instruments like regulations, in addition to agri-environmental payments were used. There was concern that this system was too complex and had large administrative costs as well as inefficient for the individual farmer. Attention was therefore directed to the development of economic instruments that allow farmers to optimize production accordingly, for example a tax on phosphorus in feed.

Nine different models of taxing nitrogen were analysed. Nitrogen can be taxed both when it is applied to the field and as calculated surplus, the tax can be directed at the individual farmer and at the agricultural sector as a whole. It is important to tax all sources of nitrogen, or there will be substitution between nitrogen sources and the surplus will not decrease. The analysis shows that a tax on the nitrogen surplus on the sector level is the most cost-efficient model, included administration costs. There is however, some uncertainty connected to the level of the tax. A theoretical model may be used to estimate the optimal tax level, but farmers may not react as predicted by the model and may apply more nitrogen than economically optimal. Changes in other prices may also influence farmer behaviour. To ensure the targeted environmental effect, the tax may be somewhat higher than the rate suggested by the model.

A tax on phosphorus was also analysed. Surplus phosphorus in the soil is a problem particularly on land with high livestock density. A separate working group considered many different measures for reducing phosphorus surplus in the soil, including different tax schemes. A tax on phosphorus in feeds was considered easy to administrate, followed by a 
tax on phosphorus in mineral fertilizer. A tax on the surplus phosphorus in the agricultural sector would be more related to the environmental effect and contribute to better distribution of animal manure. However, such a scheme is relatively hard to administrate. A tax on phosphorus in animal feeds was implemented in 2005.

A trading quota scheme is economically attractive because it (theoretically) insures a cost-effective reduction in nutrient leakage. Each farmer will get a quota of nutrients that can be applied to the land. A market for trading quotas will then be established and farmers can either buy or sell excess quotas. The scheme will insure that reductions are done where this has least costs and additional nutrients will be applied only where this is profitable. A quota scheme is preferable to a tax when the environmental effects of the amount of surplus nutrients are known, but not the individual costs. When distributing the quotas, it is possible to take into account the geographical differences and other factors that influence the leakage of nutrients. Especially vulnerable areas can receive a smaller quota and get limited trading possibilities. This will, however, increase the administrative costs of the scheme. Trading the quotas will also imply higher transaction costs for the farmers than a tax scheme.

The working group evaluated the existing regulations on nitrogen application and found the regulations on point-source emissions to be both necessary and efficient. The nitrogen standard that limits how much nitrogen a farmer can apply to the land can motivate the farmer for optimal distribution of nitrogen, especially manure. The standards are formed such that all farmers must reduce their use of nitrogen by the same\%age below the economically optimal. However, as the standard is based on averages, some farmers will be more restricted by the standard than others and have a larger economic loss. Neither does the standard take into account the socioeconomic costs of nitrogen leakage, which are greater in some areas than others.

Finally, the working group analysed the socioeconomic costs of using three policy instruments to reduce nitrogen leakage 5-50\% more than the APAE II target. A tax on nitrogen in fertilizer was the most costefficient instrument, especially at a 5 and $10 \%$ reduction target. The analysis showed that there is great cost-efficiency in replacing existing regulations on nitrogen applications by a tax on nitrogen. In this analysis, all side effects of the instruments were not included. Other instruments may have greater positive effects on ammonia and greenhouse gas emissions and on the natural environment. 


\subsubsection{The APAE III and its mid-term evaluation}

The third action plan for 2004-2015 has a stronger focus on phosphorus emissions and included further measures to reduce nitrogen discharge.

The aim in the Action plan was to reduce the phosphorus surplus by $25 \%$ by 2009 . The mid-term evaluation found that phosphorus surplus was reduced by around $23 \%$ in $2007 / 2008$. The fulfillment of the 2009 target was considered within reach. This was mainly due to an increase in the price of phosphorus in feeds. In order to fulfill the $50 \%$ reduction target by 2015 , there have to be a reduction of 1,000 tons of surplus phosphorus every year. This will depend on livestock production and the price of mineral fertilizer in the coming years, which is hard to predict (Waagepetersen et al. 2008a).

Table 3: Measures and targets in APAE III

\begin{tabular}{|c|c|c|}
\hline Measure & Target & Evaluation \\
\hline $\begin{array}{l}\text { Tax on mineral phosphorus in animal feed, DKK } 4 \text { per } \\
\mathrm{kg}\end{array}$ & $25 \%$ reduction by 2009 & $\begin{array}{l}\text { Midterm target probably } \\
\text { achieved }\end{array}$ \\
\hline New knowledge about phosphorus balance & 3.000 tons reduced & $?$ \\
\hline $\begin{array}{l}\text { Almost } 30.000 \text { hectares of new, crop-free buffer } \\
\text { zones around streams and lakes established by } 2009\end{array}$ & $\begin{array}{l}\text { Expected to reduce } \mathrm{N} \text { by } \\
\text { approx. } 960 \text { tons }\end{array}$ & $\begin{array}{l}\text { Not achieved, low participa- } \\
\text { tion in voluntary program }\end{array}$ \\
\hline \multicolumn{3}{|l|}{$\begin{array}{l}\text { Further establishment of } 20.000 \text { hectares of buffer } \\
\text { zones before } 2015\end{array}$} \\
\hline $\begin{array}{l}\text { Structural development, set-aside land, improved } \\
\text { feed utilization and EU reform, land change for roads, } \\
\text { etc. }\end{array}$ & $\begin{array}{l}\text { Expected to reduce } N \text { with } \\
11.200 \text { tons by } 2015\end{array}$ & Did not happen \\
\hline Afforestation $20.000-25.000$ hectares & $\begin{array}{l}\text { Expected to reduce } \mathrm{N} \text { by } \\
\text { approx. } 900 \text { tons }\end{array}$ & $\begin{array}{l}\text { Afforestation achieved, but } \mathrm{N} \\
\text { reduction failed }\end{array}$ \\
\hline $\begin{array}{l}\text { Tightening regulations on catch crops, } 6-10 \% \text { of land } \\
2005-2009,10-14 \% \text { of land } 2010-2015 \text {. }\end{array}$ & $\begin{array}{l}\text { Expected to reduce } \mathrm{N} \text { by } \\
\text { approx. } 4.600 \text { tons }\end{array}$ & $\begin{array}{l}\text { Reduction lower than ex- } \\
\text { pected }\end{array}$ \\
\hline $\begin{array}{l}\text { Tightening in requirement for utilization of nitrogen } \\
\text { in livestock manure }\end{array}$ & $\begin{array}{l}\text { Expected to reduce } \mathrm{N} \text { by } \\
\text { approx. } 2.900 \text { tons (by 2011) }\end{array}$ & $\begin{array}{l}\text { Achieved, but counteracted } \\
\text { by changes in ammonia use }\end{array}$ \\
\hline Establishment of further 4.000 hectares of wetlands & $\begin{array}{l}\text { Expected to reduce } \mathrm{N} \text { by } \\
\text { approx. } 1.100 \text { tons }\end{array}$ & Achieved \\
\hline General agro-environmental measures & $\begin{array}{l}\text { Expected to reduce } \mathrm{N} \text { by } \\
\text { approx. } 400 \text { tons }\end{array}$ & $\begin{array}{l}\text { Probably not achieved, low } \\
\text { participation }\end{array}$ \\
\hline $\begin{array}{l}\text { Tightening in requirement for utilization of nitrogen } \\
\text { in mink manure }\end{array}$ & $\begin{array}{l}\text { Expected to reduce } \mathrm{N} \text { by } \\
\text { approx. } 100 \text { tons }\end{array}$ & Achieved \\
\hline $\begin{array}{l}300 \mathrm{~m} \text { buffer zones around particularly vulnerable } \\
\text { areas, approx. } 180.000 \text { hectares }\end{array}$ & & \\
\hline
\end{tabular}

Adapted from VMP3 and Børgesen et al. (2009) 
The purpose of the tax on mineral phosphorus in feed stuff was to motivate livestock farmers to use feed with a lower concentration of mineral phosphorus and added phytase. An evaluation of this tax found that the increasing international price of mineral phosphorus had probably reduced the consumption of $\mathrm{P}$ independently of the tax which amount to a very small part of the market price (Miljøministeriet 2008). Consumption of mineral phosphorus decreased from 13.000 tons to 10.000 tons between 2003 and 2008, while a reduction of 5.000 tons was expected (Jacobsen et al. 2009). The evaluation report suggests that the tax can be increased and that more research and information about the use of phytase in animal feed is needed.

Another measure to reduce P-leakage was riparian buffer zones along streams and lakes. From 2005-2009, almost 30.000 ha of buffer zones were supposed to be established according to the APAE III. This land use change is voluntary and supported by a payment as compensation. However, only 700 ha of new buffer zones were established and a mapping of the area around streams and lakes found a decrease in riparian buffer zones by 4.000 ha (Bro 2008). Land kept fallow along streams and lakes were counted as buffer zones. But as the EU set-aside scheme was repealed in 2008, much of this land was cultivated which further reduce the total area of buffer zones (Waagepetersen et al. 2008a). More set-aside land will probably be cultivated again, further reducing the area of uncultivated buffer zones.

The mid-term evaluation of the APAE also included an analysis of the costs and effectiveness of measures implemented the planning period from 2005 to 2009 (Jacobsen et al. 2009). The analysis was based on the environmental effects found in the main mid-term evaluation (Waagepetersen et al. 2008a). The analysis showed that some of the measures did not have the expected effect on reduction of $\mathrm{N}$-leakage. Only the change in the regulation in use of manure from mink farms led to a larger reduction than expected.

The creation of wetlands was more cost effective under the second APAE when only a one-time investment support was paid and the requirements for N-leakage reduction were higher. The effect from this measure was also smaller because a smaller area of wetlands than expected was established. Catch crops is a very cost efficient measure, but the APAE allows farmers, under certain circumstances, to replace it with winter-green fields. Winter crops are, however, not as effective in reducing N-leakage as catch crops. Area with afforestation is larger than expected, but did not have the expected effect on total N-leakage. This is 
because implemented measures such as afforestation allows for increased nitrogen application on other areas.

Total cost of the APAE III measures was as expected but the reduction of phosphorus surplus had higher cost than expected. Total costs of measures to reduce $\mathrm{N}$-leakage was lower than expected as some measures had a lower cost than budgeted and other measures had not been implemented (Jacobsen et al. 2009). The cost per kg nitrogen reduction was twice of the expected, i.e. the cost efficiency was much lower than expected. One reason for this is that afforestation had much lower environmental effect while the cost per ha was slightly higher than expected.

\subsubsection{EU's set-aside land scheme}

One of the measures following the CAP "Health check" was the abolition of the set-aside land scheme. Previously, farmers were obliged to keep $10 \%$ of their land uncultivated. In 2007, this amounted to 148.000 ha in Denmark (Waagepetersen et al. 2008b). In 2008, the set-aside area was reduced by around 83.000 ha and the long-term expected increase in cultivated area was from $80.000-120.000$ ha (ibid.). This increase in cultivated area would lead to a long-term increase in N-leakage by $300-$ 500 tons per year, increase in ammonia emissions by $1.300-1.900$ tons per year and an increase in CO2 emissions by 110.00-170.000 tons per year. Short-term consequences, i.e. the two first years, were much higher than long-term effects since the fixed nitrogen quota later lead to a decreased amount of nitrogen per ha applied. Transforming the set-aside land into cultivated land will also increase the use of pesticides.

To counteract the environmental consequences of the cultivation of set-aside land, the Danish government made an action plan early in 2008 (Miljøministeriet 2008). According to APAE III the requirements for catch crops were supposed to increase with $4 \%$ from 6 or $10 \%$ (according livestock density) in 2009. This was implemented in 2008. Farmers who volunteer to keep buffer zones uncultivated and establish new buffer zones were allowed to increase their N-quota on the other land. An information campaign was also launch to inform farmers about the environmental value of set-aside land, support measures and regulations. Despite these efforts, around $80 \%$ or 115.000 ha of the set-aside land were cultivated in 2009 (Normander et al. 2009). 


\subsubsection{The Green Growth Agreement}

The Danish government launched the Green Growth Agreement (GGA) in 2009, a comprehensive plan for Danish agriculture and environment. The agreement includes the APAE objectives, Denmark' obligations through the Water Framework and Natura 2000 Directives, a follow-up on the Pesticide Plan, and implements the Rural Development Program for 2010-2013. It also includes a broad strategy on how to meet environmental objectives and at the same time allow the agricultural sector to grow.

By green growth the government means a development in the agricultural sector that is not a burden on the environment (Regeringen 2009b). Such a development requires changes and cause transition costs. The government estimated that the cost for the agricultural sector as a consequence of new regulations was on average DKK 621 million every year from 2010 to 2015 . The government planned to spend DKK 513 million each year on compensations and payments for voluntary measures. Compensations are only paid for areas taken out of production and which leads to lower production and thereby lower income possibilities for farmers. The government will also increase spending on the agricultural sector, in particular on green technologies and organic production.

The GGA was revised and a second agreement, version 2.0, was made in 2010. In this version, the agricultural sectors economic sustainability and its significance for rural economies was emphasized even more than in the first version (Regeringen 2010). The new agreement has the same targets for nitrogen reduction, but states that more analysis is needed to map the consequences of the Danish River Basin Management Plans (RBMP), the implementation of the Water Framework Directive, for the agricultural sector. The new version also included additional measures, among them a property tax relief for agricultural land. Farmers, however, were not content.

The development of the 23 RBMPs started in 2007 and they were sent for public hearing from October 2010. There was early concern about how the implementation of the RBMPs would affect the agricultural sector - unless the measures were cost-effective and with positive side-effects (Ministeriet for Fødevarer, Landbrug og Fiskeri og Miljøministeriet 2008). An analysis of the costs of the implementation of suggested measures, shows that the agricultural sector must bear two thirds of the total costs at the suggest method of funding (Iversen et al. 2009). For example, it was suggested that the farmers take the full cost of reducing 
the nitrogen-norm, increase area with catch crops and stop tilling in the fall (ibid.).

In the autumn 2012, the Danish Agriculture and Food Council took the Ministry of Environment to court because they believe implementation of the plans did not happen correctly. In December 2012, the RBMPs were withdrawn for a new hearing. The new government, which is not bound by the GGA, established an independent "commission for the environment and agriculture" which objective is to suggest solutions that will solve the economic and environmental challenges faced by Danish agriculture (www.naturoglandbrug.dk). The commission published a comprehensive status report in autumn 2012 that will form the basis for suggested developments for the sector.

\subsection{Soil conservation in Iceland}

This section presents the soil conservation policies in Iceland which have successfully led to the restoration of degraded areas. Unlike many European countries, Iceland has large areas of desert-like, barren areas where wind and rain move the soils. Overgrazing by sheep has contributed to this in a way that resembles the "tragedy of the commons". This section draws heavily on a journal article by Arnalds and Barkarson from 2003 and a contribution by Arnalds to a conference in 2006.

Sheep meat production is largely based on the resources in the common high lands where the sheep graze in the summer (Jóhannesson 2010). The right to use these lands for grazing is based on old traditions. Farmers also have grazing areas on their own lands and usually house their sheep from November to May. Use of pesticides and fertilizers are very limited in Iceland and nitrogen and phosphorus pollution in rivers and lakes is an unknown problem as measured run-off from fields is within natural range. Soil erosion and desertification are severe environmental problems with adjoining policies which will be discussed here.

Since human settlement 1100 years ago, a large share of Iceland's terrestrial ecosystems has been devastated (Arnalds and Barkarson 2003). The ecosystems developed without large grazing animals and reconstructing suggests that most of the island was fully vegetated when man came with livestock and started wood harvesting. Sheep grazing altered the ecosystems and made them more vulnerable and less productive. Cold spells, ash-fall from volcanic activity, sand encroachments from glacier margins also contribute to soil degradation. 
In 1991, a national survey was initiated to map Icelandic soil erosion. The most common soil type, Andosols, consist of volcanic materials that are very sensitive to water and wind erosion when not protected by vegetation. The surveys mapped the erosion problems in the Icelandic highlands and revealed that serious soil erosion was present on about $40 \%$ of Iceland (Arnalds 2006). This spurred the process of reviewing existing agricultural policy and develops new solutions for combatting the soil degradation (Arnalds and Barkarson 2003) and put an end to the wide disagreement between land users and conservation interests on the extent and seriousness of soil erosion (Arnalds 2006).

The interior of Iceland consist of highlands which are mostly common grazing areas for sheep. The first centuries of settlement reflected a good understanding of the limits of the grazing lands, with strong property rights that required owners to keep the livestock on own land (Arnalds 2006). However, this did not last as increased grazing and demand for wood and agricultural land, in combination with volcanic eruptions and climatic fluctuations started a process of dramatic degeneration with soil erosion and desertification. Originally, at least $25 \%$ was covered with woodland. In the 2000 s, only $1 \%$ of Iceland's area is covered by woods.

Efforts to mitigate soil erosion and desertification started early in 1907 with the establishment of the Soil Conservation Service (SCS). Measures were undertaken to stop rapidly advancing soil erosion and were locally successful. However, on a national scale the degradation continued as the roots of the problems were not addressed (Arnalds 2006).

The local communities have grazing rights in the commons. Grazing management, including length of grazing period and animal density is decided by the district councils. Practices vary between districts, but incentives to protect sensitive areas from grazing are commonly not present. The number of sheep in Iceland has varied greatly, with at peak around 1977 with 896.000 sheep. In the 2000s, the number of sheep was almost halved to 460.000 sheep. The large number of sheep was supported by export subsidies, which is now provided as a direct payment per sheep head. The government has spent considerable resources to reduce the number of sheep and there are now fewer sheep farms although they have a larger number of animals. 
A new subsidy scheme was implemented in 2000 where farmers have a production quota entitled to subsidy. Additional contracts were made between the government and farmers on a voluntary basis, where farmers had to meet certain criteria of "quality management" to receive additional support. Sustainable land use was part of the criteria which, according to Arnalds and Barkarson (2003) will include the withdrawal of some commons for grazing as they are unsuitable for this. A Farm Land database which mapped all farmland in Iceland was developed in the early 2000s. This database is used to define the sustainable land use criteria, which will set a limit for how much half-vegetated and denuded land a farm can have and restrain the use of commons where soil erosion is active or characterized by deserts (ibid.). Farmers not meeting these criteria must undertake measures to improve their land, such as re-vegetation, improve grazing management or even restrict grazing and land use change (Arnalds 2006).

The important development in this policy is that subsidies for sheep farming are linked with sustainable land use. This development was partly led by farmers who needed to improve the image and quality of their products. The link also gives incentives to concentrate future sheep farming in areas with appropriate resources. Arnalds and Barkarson (2003) believe that financial incentives is not enough to stop unsustainable grazing in commons and suggest that land not suitable for grazing needs protection by law.

The Soil Conservation Service (SCS) of Iceland has played an important role in re-vegetating much of Iceland's area. SCS has administered two successful land management programs, "Farmers heal the land" and a Land improvement incentives program. In the first program, a cooperative of farmers receive $85 \%$ of the costs of fertilizer and seeds necessary for re-vegetating devastated lands. Farmers use their own machines and labour, which creates a sense of ownership and enhances local knowledge. The program is based on trust rather than bureaucracy (Arnalds 2006). The second program is directed to larger projects where the recipients are land care groups and district authorities.

One of the government's five principal objectives related to climate change is directly linked to soil degradation:

The government will attempt to increase carbon sequestration from the atmosphere through afforestation, revegetation, wetland reclamation, and changed land use (Ministry for the Environment 2007). 
GHG emissions from Icelandic agriculture have been declining slightly from 1990 to 2004 and were $13.4 \%$ of total emissions in 2004. Further reductions from conventional agriculture are considered difficult without also reducing production. However, significant potential in carbon sequestration in soil and vegetation is present (Ministry for the Environment 2007).

\subsection{Taxes and other policies for reducing greenhouse gas emissions from agriculture}

\subsubsection{The Swedish nitrogen tax}

This chapter draws heavily on an article by Kristina Mohlin (2012) which evaluates the impact of Swedish fertilizer tax on nitrous oxide (N20) from agriculture. Another article by Wirsenius, Hedenus and Mohlin (2010) which proposes a tax on animal feed to reduce greenhouse gas emissions from European countries is also presented. Other studies of the impact of taxes on nutrient leakage and greenhouse gas emissions from the Nordic countries are also presented.

Sweden introduced a tax on synthetic fertilizer in the 1984 in order to reduce nitrogen and phosphorus leakage to water. From 1994 the charge was approximately SEK 1.80 per kg N. In 2010, the Swedish government passed a bill that abolished the tax on fertilizer and at the same time reduced the deductions on the $\mathrm{CO} 2$ tax on diesel for farmers. The stated intention of abolishing the tax was to enhance the competitiveness of Swedish farmers. However, it can also be seen as a compensation for raising the $\mathrm{CO} 2$ tax on diesel. If the tax on nitrogen was reducing N2O emissions, the result may be an increase in greenhouse gas emission because $\mathrm{N} 2 \mathrm{O}$ is a very much more potent GHG than $\mathrm{CO} 2$.

Mohlin's (2012) estimate the price elasticities of $\mathrm{N}$ by using panel data from the counties of Sweden and compare these with an estimate of the price elasticity of aggregate $\mathrm{N}$ sales in Sweden. Earlier studies from Sweden have found the own-price elasticity of nitrogen to be between 0.1 and -0.5 , which means that $1 \%$ increase in the price of fertilizer will lead to between 0.1 and $0.5 \%$ decrease in the quantity purchased. Demand for fertilizer also depends on agri-ecological conditions and in other countries price elasticity have been found to be as high as -0.8 (Greece). 
In a UN IPCC report, N2O emissions from agricultural soils are estimated as a linear function of applied nitrogen (IPCC 2006). However, this relationship may not be linear, as suggested by a study by Van Groeningen et al. (2010). They wanted to find out how N2O emissions from agricultural soils can be minimized and still provide acceptable yields. In general, $\mathrm{N} 2 \mathrm{O}$ emissions are expressed as a function of $\mathrm{N}$ application such that smaller $\mathrm{N}$ application always leads to smaller $\mathrm{N} 2 \mathrm{O}$ emissions. A meta-analysis of yield-scaled N2O emissions by non-leguminous annual crops revealed that the best strategy to reduce $\mathrm{N} 2 \mathrm{O}$ emissions is to use median rates of $\mathrm{N}$ inputs, not minimizing it.

Mohlin (2012) uses the emission function estimated by Van Groeningen et al. (2010) where nitrogen surplus is an exponential function of nitrogen applied. The own-price elasticity of the average $\mathrm{N}$ application rate was estimated to be -0.4 for cereals, -0.5 for ley (grass) and -0.3 for other crops. The estimated price elasticities seemed to relate well to the advice farmers get from the Swedish Board of Agriculture on economically optimal application rates. These results were used to simulate N2O emissions from agricultural soils from the cultivation years from $1989 / 99$ to 2008/9. The results suggest that over the decade the annual average direct level of $\mathrm{N} 20$ emissions from Swedish agricultural soils would have been 240 tons higher without the tax. In CO2 equivalents, this translates into 74.000 tons of $\mathrm{CO} 2$. In comparison, a crude estimation shows that the increase in the $\mathrm{CO} 2$ tax on diesel results in a reduction in CO2 emissions by 40.000 tons in 2007 (as an example year). This calculation suggests that the impact of the policy change is an increase in GHG emissions from agriculture.

Mohlin's study raises another interesting aspect of GHG emission calculations. If the exponential function of $\mathrm{N} 2 \mathrm{O}$ emissions is a better representation of the true relationship between nitrogen application and soil N2O emissions, this will have implications for the calculation of the national GHG inventory. If removal of the nitrogen tax leads to a significant increase in $\mathrm{N} 20$ emissions, the emission will be underestimated in the official GHG figures because of the linear function used in calculation of the national GHG inventory. More research is needed to clarify the relationship between nitrogen application and N2O emissions from agricultural soils in order to improve GHG accounting and develop efficient policy instruments to reduce such emissions.

Bonesmo et al. (2012) take a holistic view of the farm to analyse the relationship between GHG intensities and profits. A better understanding of this relationship can help policy makers reach emission reduction targets. They analysed 95 crop production farms and estimated the farm 
scale GHG emissions and gross margins. Estimations of N20 emissions were based on the linear function developed by IPCC (2006) and detailed data on soil and weather. The model used farm level agronomic and economic data for the year 2008. The results showed that N2O constituted the largest part of total GHG emissions, accounting for $45-49 \%$. The second largest contributor was off farm manufacturing of inputs, except for oilseed where it was change in soil carbon. Large variations in estimated GHG emission intensity, both per ha and per DM (output) can be explained by differences in soil carbon change, but there were also variations in $\mathrm{N} 20$ emissions. On the whole, there was also a decrease in GHG emissions per ha and DM with increasing gross margins. High fertilizer efficiency can explain this. In other words, farmers may have economic incentives to reduce emission intensities and optimization of fertilizer use may be an effective measure to reduce emissions. Another suggested measure, reduced tillage, did not have significant impact on GHG emissions.

\subsubsection{Tax on animal food products}

The study by Wirsenius et al. (2010) assesses the potential of GHG weighted consumption taxes on animal food products in the EU27 countries. The impact of such taxation on land change and food production and additional mitigation potential from freeing land for growing crops for bioenergy is also estimated. The latter notion makes this an interesting study for green growth in agriculture. One disadvantage of such a tax scheme, like other consumption taxes, is the impact it has on the distribution of the household disposable income. There are solutions to this problem, e.g. changes in income tax, which is not discussed further by Wirsenius et al.

The inclusion of non-CO2 greenhouse gases in climate policy instruments would affect agricultural sector as this sector is responsible for about $60 \%$ of these emissions (IPCC 2007). There seems to be different opinions of the costs of reducing GHG emission in agriculture, but more agreement on the barriers to implementation of climate policy for this sector because of high transaction and monitoring costs. Wirsenius et al. (2010) argue that these circumstances may favour output taxes, i.e. a consumption tax, rather than a tax on emissions of methane and nitrous oxide. Animal food products such as meat have high emission intensities, high substitutability in consumption and large divergences in emissions per food unit. A tax on meat that is differentiated by GHG emissions per 
food unit could be a cost-effective policy for reducing agricultural GHG emissions in EU.

A tax on output rather than a tax on emission is preferable if (1) monitoring costs are high, (2) it is hard to reduce emission without reducing output level, and (3) the output is easily substitutable (Schmutzler and Goulder 1997). Earlier studies show that GHG emissions from agriculture have decreased over time and will continue to do so due to increases in productivity and technological and agronomic mitigation measures. In developed countries, the scope for reducing GHG emissions and the cost-effectiveness of mitigation measures are relatively low. There are some technological and agronomic measures like altered animal feed, improved manure management and fertilizer efficiency, which have the potential to reduce GHG emissions by $10-20 \%$ in the EU (Wirsenius and Hedenus 2010). There is, however, substantial potential in reducing GHG emission by substituting some animal foods with others. If cattle beef is substituted by pork and poultry meet, GHG emissions are reduced by $80 \%$. The potential mitigation is even higher if protein requirement in human diet is fulfilled with beans instead of beef. An emission differentiated tax should be levied at the consumption level in order to avoid emission leakage and creating a cost disadvantage for EU farmers.

Wirsenius et al. (2010) use a model of the EU27 food and agriculture system to estimate land use change and GHG emissions related to a change in food consumption. Where land would be converted from permanent pasture to cropland because of production changes, $\mathrm{CO} 2$ emissions were taken into consideration. The tax would need to be weighted according to average emission intensity of the actual food category. Emission intensity included $\mathrm{CO} 2$ from fuels used on farms. Food consumption changes were seen in the long term.

The estimations revealed that if the tax rate was set to EUR 60 per ton $\mathrm{CO} 2$ equivalent, net reductions would be 32 million tons $\mathrm{CO} 2$ equivalents or $7 \%$ of current GHG emissions from agriculture in EU. The main reductions in emissions come from reduced consumption of ruminant meat. The tax per kg meat would EUR 1.4 per kg if ruminant meat, an approximate price increase of $16 \%$. Consumption of pig and poultry increased due to substitution effects, and the increase in emission from this production result in a net reduction that is around $10 \%$ smaller than if this increase had not happened. Around 11 million ha of permanent pastures and 4 million of cropland were taken out of production, which constitutes 16 and $3 \%$ of current agricultural land, respectively.

If the land taken out of production is used for bioenergy that replaces fossil fuels, additional mitigation can be achieved. There are several 
ways in which this can happen, different crops that can be used for biofuels, which affect the GHG emissions. For example, growing wheat and rapeseed for bioethanol and -diesel, result in a relatively small net GHG emission reduction. Net mitigation is much larger if former pasture land is used to grow lignocellulosic crops. In the most effective scenario, when lignocellulosic crops replace coal in power generation, net GHG emission reductions exceed that of changes in food consumption.

The analysis has several shortcomings and factors that are not included are e.g. impacts on imports of animal food. It does, however, clearly show that ruminant livestock production account for the greatest part of GHG emissions in EU and replacing this with other meats and foodstuffs will reduce emissions. A tax on ruminant products only would still lead to $80 \%$ of mitigation from the tax on all animal foods and reduce administration costs. When freed agricultural land is used for bioenergy, potential mitigation is even larger.

In Wilsenius et al.'s discussion, they point out that a GHG weighted tax on animal food should not be the only instrument to mitigate emissions from agriculture. An output tax does not provide the incentives to exploit and develop technical and agronomic reduction potentials. Regulations and standards can complement the output tax to ensure that best practices are used. Other aspects of the impact of the tax are also worth discussing. Permanent pastures can be of significant value to biodiversity and landscape conservation. Such pastures may be preserved through direct subsidies. The loss of soil carbon and carbon sinks that exists in permanent pastures may be more severe. By replacing the permanent pastures with bioenergy crops would still result in net GHG mitigation most places.

\subsection{The potential of biofuels for mitigating climate change and water quality}

This chapter first briefly explains the processes of biogas production. Then it presents a few, selected evaluations and analysis of the prospects of using agricultural products and wastes for the production of biogas, especially in Sweden and Denmark. The focus is on aspects of policies that affects agricultural production and in particular, nutrient run-off and GHG emissions from agriculture. 


\subsubsection{Biogas systems}

Biogas can be produced from a wide range of raw materials, from dedicated energy crops to organic wastes. The actual production is a natural process where microorganisms degrade organic materials under conditions without oxygen, called anaerobic digestion (International Energy Agency 2005). The product called biogas consists of $50-80 \%$ methane (CH4), 20-50\% carbon dioxide (CO2) and some traces of other gases, e.g. 0-0.4\% hydrogen sulphide (H2S) (Lantz et al. 2007). Biogas can be used for different energy services, e.g. heat and power, and with upgrading it can be used as fuel for vehicles. Common feedstock for biogas production is sewage sludge, animal manure and other agricultural wastes, energy crops like corn, industrial wastes and municipal solid wastes. Biogas is a CO2-neutral source of energy and leads to reduced GHG emissions when it replaces fossil fuels.

In addition to the biogas, the anaerobic digestion transforms the feedstock into digestate that can be used as fertilizer. The digestion process increases the plant availability of nitrogen, thus increases the fertilizer efficiency of the feedstock (Börjesson and Berglund 2007). The production plants come in many sizes, from the large-scale centralized plant with digester volumes of 4.650-6.000 m3 common in Denmark, to farm-scale with simple technology more common in China (International Energy Agency 2005). The target for the EU is that renewable sources comprise $20 \%$ of energy by 2020 , in which biogas will be an important contributor.

\subsubsection{Environmental benefits of biogas}

This section draws on an article by Börjesson and Berglund published in journal of Biomass and Bioenergy (2007) which is based on Swedish conditions and use a life-cycle perspective when analysing the environmental impact of biogas systems. Biogas systems are different and environmental impacts differ according to feedstock, digestion technology and field application of digestates. Total environmental impact also depends on what energy system the biogas replaces, concerning waste handling and farming practices. Börjesson and Berglund (2007) analysed six different end-use technologies. Six raw materials are analysed, of which 4 are agricultural; ley crops, straw, tops and leaves of sugar beets and manure from pigs. Only the environmental impact of using feedstock from agriculture is presented here. The biogas systems are compared to reference energy systems that are realistic Swedish alternatives to energy from biogas. 
Danish calculations show that by replacing conventional storage systems for manure with anaerobic digestion, emissions of methane can be reduced by on average $1.6 \mathrm{~kg}$ per ton of pig slurry (this may be overestimated). By reducing on-farm storage time, reduction potential is larger. Reductions in ammonia and nitrous oxide depends on how the storage system on the farm. Spreading of digestate on the field may increase ammonia emissions slightly due to the higher content of ammonium which can potentially be converted to ammonia. Nitrous oxide emissions are reduced as the digestate contains less energy for the oxide-forming bacteria. Estimated reduction of nitrous oxide emission is between 25 and $40 \mathrm{~g}$ of $\mathrm{N} 20$ per ton of manure. By harvesting the tops and leaves of sugar beets, nitrogen loss can be reduced by $30 \mathrm{~kg} \mathrm{~N}$ per ha per year where one third is potential ammonia emission. Field tests in southern Sweden showed that the recovery of tops and leaves of sugar beets reduce nitrogen leaching by $25-30 \%$.

The introduction of a biogas system may lead to land use change which may affect nutrient leaching. When ley crops replace fallow land, nitrogen leaching is increased by $5 \mathrm{~kg} \mathrm{~N}$ per ha per year. If ley crops replace willow, leaching is reduced the same amount. By applying digestate instead of conventional liquid manure, $\mathrm{N}$ leaching is reduced with $7.5 \mathrm{~kg}$ per ha per year. Field trials in southern Sweden found that leaching can be reduced by $20 \%$ by replacing undigested manure with digestate. In Denmark, field trials are ambiguous and Hamlin et al. question the effect on reduced eutrophication potential from using digestate on the fields because it is small and uncertain.

Normally, the nitrogen available to plants corresponds to $70 \%$ of total nitrogen content while digestate contain about $85 \%$ available nitrogen. Differences in the plant available nutrients would have to be balanced by production of commercial fertilizers with extra energy use.

\begin{tabular}{|c|c|c|}
\hline $\begin{array}{l}\text { Environmental impact when biogas replace fossil for } \\
\text { heating }\end{array}$ & Extent & System with largest impact \\
\hline Reduction in GHG emissions & $75-90 \%$ per MJ heat & Manure \\
\hline $\begin{array}{l}\text { Reduction in acidity potential (SO2 emissions) and eu- } \\
\text { trophication potential (PO4 leaching) }\end{array}$ & $\begin{array}{l}\text { Up to } 95 \% \text { per MJ } \\
\text { heat }\end{array}$ & $\begin{array}{l}\text { Manure and tops and leaves of } \\
\text { sugar beets }\end{array}$ \\
\hline Decrease in particle emissions & $30-70 \%$ & Manure \\
\hline
\end{tabular}

When biogas is used to generate heat and power and replace fossil fuels in transportation vehicles, the impacts are similar but smaller in extent. The environmental impacts of using ley crops for biogas is sometimes 
negative when compared to cultivation of willow for methanol production. This is because the ley production has a lower energy output per ha and more gas is needed to obtain the same amount of energy which leads to increased GHG emissions.

The analysis has several potential uncertainties. The biogas, mainly methane, is in itself a potent GHG. If leakage from the production plant is not controlled, the emissions of methane can increase contribution to climate change. In Börjesson and Berglund's (2007) analysis losses of methane is estimated to be $1 \%$ when the biogas is used for heating and $2 \%$ when used as transportation fuel. Losses of methane during upgrading and pressurizing have in some cases been reported to be as much as $13 \%$ of gas treated at the upgrading plant. Losses of methane must be from $10-32 \%$ depending on the technology before the biogas system exceeds the equivalent GHG emissions from the reference system.

Assumptions about eutrophication potential, mainly the leaching of nitrate to water and ammonia to air due to changed cropping practices and handling of wastes, may also be too general. Leaching may vary greatly and estimations cannot take local variations into account partly because lack of long-term field trials and limited data, which makes the estimated results somewhat uncertain.

Börjesson and Berglund (2007) conclude that biogas systems have the potential to mitigate several environmental problems. Direct effects are reduction in GHG emissions other air pollutants when biogas replace fossil fuels. Indirect effects due to changes in agricultural practices may be even more important, as leaching of nitrate to water and ammonia to air is significantly reduced when manure, crop residues and organic wastes are used for biogas production. However, the environmental impacts may vary greatly according to the feedstock used and energy service provided. Also, biogas systems are not always a positive replacement to for example willow cultivation for methanol production, where the biogas system may increase GHG emissions. To maximize the positive effects, the biogas systems must be designed and located wisely.

A life cycle analysis supported by the Danish Environmental Protection Agency found that environmental benefit of biogas production from animal slurry highly depends on the technology used in the process (Hamelin et al. 2010). A low efficiency separation technology may offset a significant part of environmental benefits. The combustion of biogas also produces NOx and N2O, which counteract some of the benefits of biogas production. 


\subsubsection{Danish biogas production}

Denmark has for many years been aware of the potential contribution from centralized biogas plants to mitigating problems in the energy sector, agriculture and environment and the development of biogas technology has been encouraged by the government. In 2008 total biogas production was $3.93 \mathrm{PJ}$ where biogas from slurry constitutes $1.06 \mathrm{PJ}$. The greatest unused potential is clearly from animal manure, potential energy was 29 PJ. A much greater part of the potential from industrial wastes and waste water is already exploited. Estimated energy potential from biogas is 60 PJ or $10 \%$ of Denmark's gross (future) energy consumption. This estimate assumes that half of the energy can come from energy crops which will be cultivated on around $6 \%$ of agricultural area (Energistyrelsen 2010).

The Green Growth agreement aims to use $50 \%$ of all animal manure for biogas production by 2020 (Regeringen 2009). This requires continued investments in new biogas plants that need to be economically sustainable and reduction in the dependence on organic industrial wastes (Energistyrelsen 2010). The use of half of all animal manure requires investments in biogas plants that produce 12 PJ per year. By supplementing the slurry with energy crops that contribute to half of the energy, 24 PJ of energy per year will be produced.

In relation to the implementation of the Green Growth agreement, additional and updated analysis environmental impact of the utilization of more manure for biogas was carried out (DFJ and DMU 2011). By utilizing $50 \%$ of animal manure for biogas, a net effect on GHG emissions is a reduction of 349.000 tons $\mathrm{CO} 2$ equivalents per year. The impact on nitrogen leaching will not change unless the regulations on utilization are changed. If application is adapted to the increased amount of ammonium, the burned manure can replace commercial fertilizer and reduce leaching in the long-term by 2.1 to $4.1 \mathrm{~kg} \mathrm{~N}$ per ha. No effect on phosphorus leaching is expected from this measure.

Energy crops will play an important role extending the biogas production from manure (Energistyrelsen 2010). In the Green Growth agreement, several measures are related to the cultivation of perennial energy crops.

- A grant scheme for planting perennial energy crops where it leads to reduction in leaching of nitrogen

- Expenses for planting energy crops are tax deductible 
- Energy crops can under certain conditions replace mandatory catch crops (this measures is not meant to have an effect on total leaching, but gives the farmers flexibility in the choice of measures (DFJ and DMU 2011))

When an energy crop like Miscanthus (Danish: Elefantgræs) replaces an annual crop like spring wheat, annual emission of nitrous oxide is reduced by $0.43 \mathrm{CO} 2$ equivalents per ha. Perennial grasses can also increase the carbon content in the soil equivalent to 1.57 tons $\mathrm{CO} 2$ per ha per year. Catch crops also absorb carbon so that replacing spring wheat and catch crops with an energy crop will result in an increase in carbon sequestration by 0.82 tons CO2 equivalents per ha per year. Some studies report higher numbers for carbon absorption by energy crops.

Perennial energy crops can also reduce the phosphorus surplus in the soil as long as applied amount of $\mathrm{P}$ is less than the amount that the crop absorbs. By applying less $\mathrm{P}$ than the plants take up, loss of $\mathrm{P}$ to water can be reduced by $0.003-0.1 \mathrm{~kg} P$ per ha in several years. Overload of phosphorus may lead to increased leaching and as there are no P-norms for energy crops, there are some uncertainties connected to how perennial crops will affect $P$ surplus and leaching. Perennial energy crops also lead to reduced use of pesticides and may have local positive impacts on biodiversity (Börjesson and Tufvesson 2011).

\subsubsection{Danish energy crops for combustion plants}

In 2010, support under the GGa was given to the establishment of 1409 ha of energy crops, mainly willow (DFJ and DMU 2011). Willow is not suitable for biogas plants but is used in combustion plants. Area with energy crops increased from around 1300 ha in 2005 to 4719. Future establishment depends on many factors, among them farmers' expectations of grain prices, energy crop prices and agricultural policy. If rate of establishment continue as before, 8.000 ha will be planted from 2010 to 2015. A great part of this establishment will probably be done as a replacement for catch crops and some will replace perennial grassland. The target in the Green Growth strategy was to establish 30.000 ha of energy crops.

The first 1-2 years after planting a perennial energy crop include some risk of $\mathrm{N}$ leaching at the same level as other crops (Schou et al. 2007), depending on the crop it replaces. In the long-term, $\mathrm{N}$ leaching is reduced by 30-45 kg N per year, on sandy soils $10 \mathrm{~kg}$ more. Total reduction in $\mathrm{N}$ leaching from the root zone depends on how much replaces 
catch crops and grassland, and whether it is established on sandy or clayey soils, but ranges from 563 tons and 1440 tons N per year.

\subsection{Summary of Nordic studies on policy measures for reduced phosphorus and nitrogen loadings in water}

Table 5 summarizes the main findings from the studies presented in this chapter.

\begin{tabular}{|c|c|c|}
\hline Study and country & $\begin{array}{l}\text { Policy instrument (or } \\
\text { change) }\end{array}$ & Lessons learned \\
\hline $\begin{array}{l}\text { Laukkanen and Nauges } \\
\text { (2012), Finland }\end{array}$ & $\begin{array}{l}\text { Agri-environmental } \\
\text { program }\end{array}$ & $\begin{array}{l}\text { The Finnish agri-environmental program (FAEP) had high } \\
\text { participation rates which implies that Finnish farmers can } \\
\text { change behaviour when compensated. Participation is not } \\
\text { random, but influenced by several factors such as age, labour } \\
\text { constraints and awareness. The FAEP resulted in a } 11 \% \text { and } 13 \\
\% \text { reduction in } \mathrm{N} \text { and } \mathrm{P} \text { loading, mainly because of reductions in } \\
\text { fertilizer use. Increase in area under cultivation was another } \\
\text { effect which reduced the total effect on water quality. }\end{array}$ \\
\hline $\begin{array}{l}\text { Lankoski and Ollikainen } \\
\text { (2011), Finland }\end{array}$ & $\begin{array}{l}\text { Agri-environmental } \\
\text { program Fertilizer } \\
\text { constraint }\end{array}$ & $\begin{array}{l}\mathrm{N} \text { loading in Finland has increased because of changes in land } \\
\text { use and a shift to more fertilizer intense production from } 1995 \\
\text { to } 2007 \text {. Without the FAEP N loadings would have been larger, } \\
\text { but } \mathrm{P} \text { loadings would have been smaller. }\end{array}$ \\
\hline $\begin{array}{l}\text { Lehtonen et al. (2005), } \\
\text { Finland }\end{array}$ & $\begin{array}{l}\text { Liberalisation of } \\
\text { agricultural policy }\end{array}$ & $\begin{array}{l}\text { Significant reduction in Finnish production } \\
\text { No reduction in nutrients loading because of intensity of } \\
\text { remaining production }\end{array}$ \\
\hline $\begin{array}{l}\text { Lehtonen et al. (2007b), } \\
\text { Finland }\end{array}$ & Decoupling of support & Decrease in nutrient loadings \\
\hline $\begin{array}{l}\text { Lehtonen et al (2007a), } \\
\text { Finland }\end{array}$ & $\begin{array}{l}\text { Full decoupling of } \\
\text { national support, } \\
\text { partial decoupling, } \\
\text { agri-environmental } \\
\text { payments, tax on } \mathrm{N} \\
\text { fertiliser }\end{array}$ & $\begin{array}{l}\text { Full decoupling most efficient in reducing nutrient loadings, but } \\
\text { no policy scenario stand out in terms of impact. }\end{array}$ \\
\hline $\begin{array}{l}\text { Fölster et al. 2012, } \\
\text { Sweden }\end{array}$ & $\begin{array}{l}\text { Agri-environmental } \\
\text { payments } \\
\text { Information }\end{array}$ & Some reduction in nutrient loadings in water \\
\hline $\begin{array}{l}\text { Elofsson (2010), Sweden } \\
\text { and Baltic Sea }\end{array}$ & $\begin{array}{l}\text { Emission permit } \\
\text { trading }\end{array}$ & $\begin{array}{l}\text { How targets are formulated influences the costs of achieving } \\
\text { them. Targets for specific catchments are more costly than for } \\
\text { the Baltic Sea as a whole. If possible, reductions should happen } \\
\text { where costs are lowest. This can be met by trading emission } \\
\text { permits. }\end{array}$ \\
\hline $\begin{array}{l}\emptyset \text { ygarden et al. 2012, } \\
\text { Norway }\end{array}$ & $\begin{array}{l}\text { Agri-environmental } \\
\text { payments for reduced- } \\
\text { and no-tillage practises }\end{array}$ & $\begin{array}{l}\text { Large regional differences in implementation could not be } \\
\text { explained by the size of the payment. }\end{array}$ \\
\hline
\end{tabular}




\begin{tabular}{|c|c|c|}
\hline Study and country & $\begin{array}{l}\text { Policy instrument (or } \\
\text { change) }\end{array}$ & Lessons learned \\
\hline $\begin{array}{l}\text { Refsgaard et al. 2010, } \\
\text { Norway }\end{array}$ & $\begin{array}{l}\text { Farmers' attitudes and } \\
\text { knowledge }\end{array}$ & $\begin{array}{l}\text { Farmers' attitudes may be imperative for adoption of no-tillage } \\
\text { practises, not profit. }\end{array}$ \\
\hline $\begin{array}{l}\text { Gunnarsdottir and } \\
\text { Refsgaard 2012, }\end{array}$ & Watershed governance & $\begin{array}{l}\text { Local involvement, agreement on targets and bottom-up } \\
\text { governance important for the achievement of water quality } \\
\text { goals. }\end{array}$ \\
\hline $\begin{array}{l}\text { Kronvang et al. (2008), } \\
\text { Denmark }\end{array}$ & $\begin{array}{l}\text { Regulatory measures } \\
\text { on fertiliser use, focus } \\
\text { on fertiliser efficiency }\end{array}$ & $\begin{array}{l}\text { Nitrogen loadings were successfully reduced in Denmark from } \\
1990 \text { to } 2003 .\end{array}$ \\
\hline $\begin{array}{l}\text { Arbejdsgruppen for } \\
\text { generelle virkemidler } \\
\text { 2003, Denmark }\end{array}$ & $\begin{array}{l}\text { Tax on nitrogen, } \\
\text { phosphorus, quota } \\
\text { trading scheme, } \\
\text { nitrogen application } \\
\text { regulations }\end{array}$ & $\begin{array}{l}\text { A tax on nitrogen was most cost-effective, but is hard to } \\
\text { impose on farmers although it gives them more freedom than } \\
\text { regulations. }\end{array}$ \\
\hline $\begin{array}{l}\text { Waagepetersen et al. } \\
\text { 2008b, Denmark (EI) }\end{array}$ & $\begin{array}{l}\text { EUs end of set-aside } \\
\text { land scheme }\end{array}$ & $\begin{array}{l}\text { The end of EUs set-aside land scheme resulted in a large } \\
\text { decrease in set-aside land in Denmark and a long-term increase } \\
\text { in } \mathrm{N} \text { losses }\end{array}$ \\
\hline $\begin{array}{l}\text { Danish Government } \\
\text { (2009) }\end{array}$ & $\begin{array}{l}\text { Green Growth agree- } \\
\text { ment }\end{array}$ & $\begin{array}{l}\text { Failed, and new efforts are undertaken to create policies that } \\
\text { can help Denmark implement the Water Framework Directive. }\end{array}$ \\
\hline $\begin{array}{l}\text { Arnalds and Barkarson } \\
2003 \text { and Arnalds } 2006\end{array}$ & $\begin{array}{l}\text { Knowledge and } \\
\text { economic incentives }\end{array}$ & $\begin{array}{l}\text { Iceland has successfully stopped land degradation cause by } \\
\text { excessive grazing }\end{array}$ \\
\hline $\begin{array}{l}\text { Kristina Mohlin (2012), } \\
\text { Sweden }\end{array}$ & Tax on nitrogen & $\begin{array}{l}\text { The tax on fertilizer reduced } \mathrm{N} 2 \mathrm{O} \text { emissions from Swedish soils } \\
\text { significantly }\end{array}$ \\
\hline $\begin{array}{l}\text { Bonesmo et al. (2012), } \\
\text { Norway }\end{array}$ & $\begin{array}{l}\text { Knowledge about } \\
\text { agronomy }\end{array}$ & Farmers can increase profit by increasing fertilizer efficiency \\
\hline $\begin{array}{l}\text { Wirsenius et al. (2010), } \\
\text { EU }\end{array}$ & $\begin{array}{l}\text { Consumer tax on meat, } \\
\text { weighted by GHG } \\
\text { emissions in produc- } \\
\text { tion }\end{array}$ & $\begin{array}{l}\text { A consumer tax will change consumption and thereby produc- } \\
\text { tion of meat such that current ( } 2010) \text { GHG emissions from } \\
\text { agriculture in EU was reduced by } 7 \% \\
\text { Net mitigation increases if agricultural area is used for growing } \\
\text { energy crops }\end{array}$ \\
\hline Denmark and Sweden & Biogas production & $\begin{array}{l}\text { By using animal manure and energy crops for biogas produc- } \\
\text { tion, nutrient losses to water and air can be significantly } \\
\text { reduced. }\end{array}$ \\
\hline
\end{tabular}




\section{Policies for sustainable agriculture and green growth}

The studies presented in chapter five contain several lessons that are important to consider when developing policy instruments for a sustainable agricultural production and green growth. This chapter identifies and elaborates on these lessons.

\subsection{Holistic perspectives are needed}

The findings in chapter five shows that it is important to consider side effects of policy instruments and that a holistic approach to policymaking is necessary. Policy-makers and the society at large often hold goals for policies for green growth in agriculture, for example rural viability, self-sufficiency, reduced GHG emissions, and reduced nutrient leaching, cultural landscapes and biodiversity, that can be conflicting. Trade-offs between different environmental goals and between socio economic goals and environmental goals have to be identified and policy-makers have to acknowledge that such trade-offs imply value judgments. Examples of such trade-offs are pesticide use and nutrient runoffs versus increases in grain production, as well as rural viability and biodiversity versus reduced GHG emissions from ruminants. Lehtonen et al. (2007) emphasize that important trade-offs exists between avoiding large reductions in the supply of domestic agricultural products (with large economic and social consequences) and yet still promote green set-aside and decreases in nutrient surpluses. Goals and policy measures for agriculture are, however, also characterized by synergy effects. Such synergy effects are important to exploit, like in Denmark where nutrient runoff policies are combined with planting of energy crops. Finally it is important to evaluate whether the costs of policy measures outweigh the benefits or not. Lankoski and Ollikainen (2011) found that the social net benefit is negative for the nutrient runoff reduction in Finland. Their conclusion is based on a willingness to pay study, and could, however, be different if other methods like multi-criteria analysis and citizen juries were used. 


\subsection{Appropriate policy measures}

When formulating policies for sustainable agriculture the studies in chapter five show firstly that it is important to choose appropriate policy measures. The policy measures described in chapter five include regulatory, economic and informational policy instruments as well as norm building policy instruments. These policy instruments could change incentives, information and preferences (Vatn, 2005). While informational and norm building instruments change information and preferences, legal and economic instruments could change incentives and preferences (Vatn, 2005). An important advantage with command-and-control instruments is that the uncertainty concerning achievement of goals are reduced. Economic instruments will, in most cases, allow farmers to reach reduction targets more efficiently than command-and-control instruments. In addition, economic instruments give incentives for development of low-cost technologies to reduce emissions. It is further important to be aware of the fact that a tax is seldom welcomed by polluters because of the increase in costs, while regulations and tradable emission permits might meet less resistance. Transaction costs are, however, generally higher with tradable emission permits than a tax. Finally, it is important to be aware that the costs of reaching the targets depend on not only measures, but on how the target is formulated (i.e. which the actual target is) (following Elofsson, 2010). Increased knowledge about how nutrients travel from agricultural soils to water and possible measures to stop this, can leave room for flexibility to choose between measures.

Informational and norm-building instruments might be important additional measures to command and control measures and they could also be used as independent policy instruments. The studies from Iceland (Arnalds and Barkarson from 2003) and Norway (Refsgaard et al. 2010) show that it is important to achieve trust in available knowledge and the study from Sweden show that it is important to educate farmers about nutrient losses. A recent OECD (2012a) report emphasize that there is a consensus in the literature cited that a financial incentive is not enough when considering behavioural drivers for farmers, although there is acknowledgement that the overall picture is not entirely clear Policy incentives, education and information and consistency and compatibility with traditional local practices, all play a determining role in 
the actual outcome of economic policy instruments (OECD, 2012a)1. The report emphasize that the assumption of purely profit maximizing behaviour is increasingly difficult to sustain and the attitudes and beliefs of farmers must be taken into account when designing appropriate incentives. Pure informational instruments will be important in the case of bounded rationality. The study from Norway showed that lack of information might explain why farmers not reduce phosphorus application as data show that it can be profitable to reduce phosphorus application. Norm-building and habit changing instruments could be important for at least for two reasons. Firstly, if farmers hold norms and habits that constrain the effects of policies it could be preferable for the society to introduce instruments that aim at change these norms and habits. Examples are when farmers have preferences for field free of weeds and this might prevent the adoption of more environmentally sound weed management. Secondly, if farmers hold intrinsic motivation concerning the production of environmental goods this might complement the effects of command-and control instruments and economic instruments.

\subsection{Appropriate point of instrument application}

The studies in chapter five show that it is important to choose the appropriate point of instrument application. Policy instruments could be attached to traded inputs like feed, fertilizers and fuel, to specific production methods like certain tillage practices, to the private goods produced like food and green tourism or to public bads (e.g. water pollution, GHG emissions) or goods (e.g. biodiversity and cultural landscape). When choosing the appropriate point of instrument application it is important to consider the characteristics of the environmental problem (the relationship between the environmental bads and goods and traded outputs and inputs as well as the production method), the information setting (degree and type of asymmetry) and transaction costs. When there is a high degree of jointness between the environmental outcomes and traded inputs or outputs it is often preferable to attach the policy instrument to traded inputs or outputs to reduce transaction costs. However, when jointness is weaker, the policy maker often faces a tradeoff between precision and transaction costs. The Danish tax on phospho-

1 This conclusion is mainly based on survey results. 
rus in feed is an example of a point of instrument application that reduces transaction costs compared to taxing phosphorus runoffs.

\subsection{Appropriate processes}

The studies in chapter five show that it is important to establish process that fosters trust and mutual learning and where the different stakeholders take part. The same policy measures can give quite different results depending on the process related to establishing and implementing these policy measures. The results from Iceland show that the national survey that mapped soil erosion was essential for putting an end to the wide disagreement between land users and conservation interests on the extent and seriousness of soil erosion. And the land management program, "Farmers heal the land" in Iceland has created a sense of ownership to the project and enhances local knowledge. The results from Norway show that participatory processes where trust and collaboration is fostered are important for farmers' adoption of measures (Refsgaard et al. 2010).

\subsection{Lessons that could be important for green growth}

Green growth has become a popular term that contains different meanings. In the Nidaros declaration by the Nordic Ministers for Fisheries and Aquaculture, Agriculture, Food and Forestry (2012) green growth were defined as increased sustainable and competitive production. OECD (2011b) emphasis that a green-growth strategy aims to ensure that enough food is provided, efficiently and sustainably, for a growing population. This means increasing output while managing scarce natural resources; reducing the carbon intensity and adverse environmental impacts throughout the food chain; enhancing the provision of environmental services such as carbon sequestration, flood and drought control; and conserving biodiversity. OECD (2011b) further emphasize that the over-arching policy challenge is to create the right incentives that would optimise resource use from an economic, environmental and social perspective. In the perspective of institutional economics (e.g. Vatn, 2005), it will also be important to build norms and motivations that take considerations for the environment, as well as the social and the economic aspects of agriculture. Caution is needed in making broad generalizations: not all government transfers (support) are harmful to growth and 
the environment; not all environmentally motivated subsidies are beneficial for the environment; and the absence of government support is no guarantee that the desired level of environmental performance will be achieved (OECD, 2011b).

One of the great challenges with agricultural policies for green growth is how to maintain or increase current food production, while at the same time to decrease the negative ecological footprints from agriculture. Possible solutions are innovation and better management practices through research, development, innovation, education, stakeholder communication and information. This could increase resource use efficiency throughout the supply chain and thereby ensure more production relative to inputs used, but also conserve scarce natural resources and deal with waste. An important measure to realize agricultural green growth could be reduced food waste. Decreased meat consumption could also be an important measure that would reduce the ecological food prints from food. Wirsenius et al. (2010) suggested introducing a tax on meat consumption to achieve this. Other measures could be increased use of precision agriculture, better utilization of manure and increase public funding of plant breeding. Finally, agriculture and forestry provide important opportunities for making green growth in the society more at large possible. Bioenergy from agriculture could be important in replacing fossil energy sources and second generation biofuel from forest could be crucial for replacing fossil fuel (Nordic Energy Technology Perspective, 2013).

Green growth in agriculture could also be seen as a development where income or the economic value of agriculture is increased without increasing food production, or even reducing food production. This could be achieved through increased production of services and value added products that receive a price premium due to specific production methods like organic or production locations (i.e. local food) without increasing inputs that causes ecological footprints. Examples of such green growth sectors in agriculture are tourism based on historical landscapes, environmental values such as bird watching and hunting. 



\section{Conclusion}

This report has looked at how agricultural policy measures, in particular payments and compensations to farmers, can be developed in order to support a sustainable agricultural production and green growth in the Nordic countries. Concerning effective policy instruments to reduce the ecological footprints from agriculture it is often emphasised that the most efficient policy instruments are to reduce agricultural production oriented subsidies, and then pay separately for the production of public goods. This could, however, hamper the achievement of other policy goals for agriculture and increase the transaction costs of policies.

Examples from the Nordic countries show that economic instruments like payments for certain measures, taxes, subsides or tradable emission permits can be used to effectively reduce water pollution from nitrogen and phosphorus and to reduce GHG emissions from agriculture. Whether these instruments should be applied to tradable input factors like fertilizers and feeds, to particular production methods, to food-products or to emissions depend on transaction costs and the interlinkages between emissions and point of instrument application. Economic instruments should, however, be complimented by information and norm-building instruments and participatory processes could be important for farmers response to these instruments. The experience from Iceland, Denmark and Norway show that agreement on the extent and seriousness of the pollution problem and how measures actually affect pollution.

Finally, correct agricultural practises can lead to increased nutrient efficiency which will lead to increased production without compromising natural resources. In order to meet future demands for agricultural products, best practices must include measures that reduce emissions of nutrients from agricultural soils. This requires research and innovation, and willingness among both policy-makers and farmers to change practices. 



\section{References}

Aakkula, J., M. Kuussaari, K. Rankinen, P. Ekholm, J. Heliölä, T. Hyvönen, L. Kitti and T. Salo (2011): "Follow-up Study on the Impacts of Agri-environmental Measures in Finland". OECD Workshop on the Evaluation of Agri-environmental Policies 20-22 June 2011. The Johann Heinrich von Thünen Institute, Bundesallee 50, 38116 Braunschweig, Germany

Andersen, J.M., Boutrup, S., Bijl, L. van der, Svendsen, L.M., Bøgestrand, J., Grant, R., Lauridsen, T.L., Ellermann, T., Ærtebjerg, G., Nielsen, K.E., Søgaard, B., Jørgensen, L.F., 2006. Aquatic and Terrestrial Environment 2004. State and trends-technical summary. National Environmental Research Institute-NERI Technical Report no. 579, $136 \mathrm{pp}$.

Arbejdsgruppen for generelle virkemidler (2003): "Forberedelse af vandmiljøplan III. Rapport fra arbejdsgruppen om generelle virkemidler. Del II." Report from the working group on general policy instruments for the development of the Action Plan for the Aquatic Environment III. Available at: http://www.vmp3.dk/Files/ Filer/Slutrapporter/del-2-10-dec-med-logo.pdf

Arnalds, A. (2006): "Policy Lessons from a Century of Soil Conservation in Iceland". In C. King, H. Bigas and Z. Adeel (eds.): Desertification and the International Policy Imperative.

Arnalds, O. and B.H. Barkarson (2003): "Soil erosion and land use policy in Iceland inrelation to sheep grazing and government subsidies". Environmental Science and Policy 6: 105-113.

Arnalds, O., F. O. Gisladottir and H. Sigurjonsson, 2001. Sandy deserts of Iceland: an overview. Journal of Arid Environment, 47, 359-371.

Battershill, M.R.J. and Gilg, A.W., 1997. Socio-economic Constraints and Environmentally Friendly Farming in the Southwest of England. Journal of Rural Studies 13(2), pp. 213-228.

Bergevoet, R.H.M., Ondersteijn, C.J.M., Saatkamp, H.W., van Woerkum, C.M.J., Huirne, R.B.M., 2004. Entrepreneurial behaviour of dutch dairy farmers under a milk quota system: Goals, objectives and attitudes. Agricultural Systems 80,1-21.

Berninger K., A. Schulman, H. Poltimäe, K. Peterson, 2011. Report on implementability of Agri-Environmental Targets in Finland. Work Package 6 of the Baltic Compass, Interreg project.

Börjesson, P. \& Berglund, M. 2007. Environmental systems analysis of biogas systems-Part II: The environmental impact of replacing various reference systems. Biomass and Bioenergy, Volume 31, Issue 5. pp. 326-344.

Boesch, D., Hecky, R., O’Melia, C., Schindler, D., Seitzinger, S., 2006. Eutrophication of Swedish seas. Rep No 5509, Swedish Environmental Protection Agency, Stockholm

Bonesmo, H., Skjelvåg, A. O., Janzen, H. H., Klakegg, O., Tveito, O.E., 2012. Greenhouse gas emission intensities and economic efficiency in crop production: A systems analysis of 95 farms. Agricultural Systems, Volume 110, July 2012, Pages 142-151.

Breen, J.P., Hennessy, T.C., Thorne, F.S., 2005. The effect of decoupling on the decision to produce: An irish case study. Food Policy 30,129-144. 
Burton, R.J.F. and Wilson, G.A., 2006. Injecting social psychology theory into conceptualisations of agricultural agency: Towards a post-productivist farmer selfidentity? Journal of Rural Studies 22, pp. 95-115.

Børgesen C. D., J. Waagepetersen, T. M. Iversen, R. Grant, B. Jacobsen og S. Elmholt (eds.) (2009): “MIDTVEJSEVALUERING AF VANDMILJØPLAN III: HOVED- OG BAGGRUNDSNOTATER”. DJF RAPPORT MARKBRUG 142, AUGUST 2009. Det Jordbrugsvidenskabelige Fakultet, Aarhus Universitet.

Börjesson P., L. M. Tufvesson (2011): "Agricultural crop-based biofuels - resource efficiency and environmental performance including direct land use changes". Journal of Cleaner Production, vol. 19, p. 108-120.

Breetz HL, Fisher-Vanden K, Garzon L, Jacobs, H, Kroetz K, Terry R., 2004. Water Quality Trading and Offset Initiatives in the US: A Comprehensive Survey. Dartmouth College. Available at http://www.dartmouth.edu/\%7Ekfv/ waterqualitytradingdatabase.pdf. Accessed in January 2013.

C. Bro (2008). Kortlægning af 10 m randzoner langs målsatte og ikke-målsatte vandløb og søer over $100 \mathrm{~m}^{2}$ i Danmark. 31pp. Ministeriet for Fødevarer, Landbrug og Fiskeri og Miljøministeriet. Available at: http://www.mst.dk/NR/rdonlyres/ 66E6308F-465E-4DAA-908B-56489B76A813/0/Kortlaegningafrandzoner.pdf

COWI (2007): "Economic analysis of the BSAP with focus on eutrophication Final report" Report prepared for HELCOM and NEFCO for the preparation of the Baltic Sea Action Plan. Available at: http://meeting.helcom.fi/c/document_library/ get_file?p_l_id=18967\&folderId=67403\&name=DLFE-26451.doc

Davies, B.B., Hodge, I.D., 2007. Exploring environmental perspectives in lowland agriculture: A q methodology study in east Anglia, UK. Ecological Economics 61, 323-333.

Defrancesco, E., Gatto, P., Runge, F., Trestini, S., 2008. Factors affecting farmers? Participation in agri-environmental measures: A northern Italian perspective. Journal of Agricultural Economics 59, 114-131.

DFJ og DMU (2011): "Notat nr. 3. Vedrørende effekter af forskellige tiltag i forbindelse med Grøn Vækst med fokus på flerårige energiafgrøder, liberalisering af landbrugsloven, energiudnyttelse af husdyrgødningen, ammoniakinitiativer, miljøgodkendelserne, reglerne for efterafgrøder og normreduktionen”. Det Jordbrugsvidenskabelige Fakultet, Danmarks Miljøundersøgelser, Aarhus Universitet. Revised report, available at: http://pure.au.dk/portal/files/48287698/280611_DJF_DMU_ notat_3_vedr_effekter_af_forskellige_tiltag_i_forbindelse_med_Gr_n_V_kst.pdf

EC (2009): "Renewable Energy Directive 2009/28/EC". The Europeian Parliament and the Coincil of the European Union.

European Environment Agency, 2005. The European environment - State and outlook 2005.

European Environment Agency, 2005. The European environment - State and outlook 2010. Marine and coastal environment. Copenhagen

European Environment Agency, 2012a. European waters - assessment of status and pressures. EEA Report No 8/2012

European Environment Agency, 2012b. European waters - current status and future challenges. EEA Report No 9/2012

Energistyrelsen, 2010. Technology Data for Energy Plants. Available at: http:// www.ens.dk/Documents/Netboghandel\%20-\%20publikationer/2010/ Technology_data_for_energy_plants.pdf

Ekholm P., K. Granlund, P. Kauppila, S. Mitikka, J. Niemi, K. Rankinen, A. Räike and J. Räsänen (2007): “Influence of EU policy on agricultural nutrient losses and the 
state of receiving surface waters in Finland". Agricultural and Food Science, vol. 16, p.282-300.

Elofsson, K. (2008): "The costs of environmental improvements in the Baltic Sea and Skagerak - A review of the literature". Swedish Agency for Marine and Water Management, report no. 5876, December 2008.

Elofsson, K. (2010): "Baltic-wide and Swedish Nutrient Reduction Targets: An Evaluation of Cost-effective Strategies". Report to the Expert Group for Environmental Studies 2010:2. Ministry of Finance, Sweden.

Swedish Environmental Protection Agency. 2006. Övergödningen av Sveriges kuster och hav: Naturvårdsverkets ställningstaganden med anledning av en internationell expertutvärdering av kväve/fosforproblematiken i våra omgivande hav. Report 5587. Environmental Protection Agency, Stockholm.

Swedish Environmental Protection Agency, 2010. Vidareutveckling av förslag till avgiftssystem för kväve och fosfor. Report 6345. Environmental Protection Agency, Stockholm.

Fölster, J., K. Kyllmar, M.Wallin och S. Hellgren (2012): “Kväve- och fosfortrender i Jordbruksvattendrag. Har åtgärdena gett effekt?". Rapport 2012:1. Institutionen för vatten och miljö, Sveriges lantbruksuniversitet. In Swedish, summary in English.

Gasson, R., 1973. Goals and values of farmers. Journal of Agricultural Economics 24, 521-542.

Gasson, R., Crow, G., Errington, A., Hutson, J., Marsden, T., Winter, D.M., 1988. The farm as a family business - a review. Journal of Agricultural Economics 39, 1-41.

Gorton, M., Douarin, E., Davidova, S., Latruffe, L., 2008. Attitudes to agricultural policy and farming futures in the context of the 2003 cap reform: A comparison of farmers in selected established and new member states. Journal of Rural Studies 24, 322-336.

Granli, T., Bøckman, O.C., 1994. Nitrous oxide from agriculture. Norwegian Journal of Agricultural Science Supplement. 12:128.

Greiner, R., Gregg, D., 2011. Farmers' intrinsic motivations, barriers to the adoption of conservation practices and effectiveness of policy instruments: Empirical evidence from northern Australia. Land Use Policy 28, 257-265.

Van Groenigen, J. W., G. L. Velthof, O. Oenema, K. J. Van Groenigen, and C. Van Kessel, 2010. Towards an agronomic assessment of N2O emissions: a case study for arable crops. European Jour-nal of Soil Science, 61(6):903-913.

Gunnarsdottir, H. and K. Refsgaard (2012): "Bridging the gap - holistic and local water governance". Presentation held during the 6th World Water Forum. Available at: http://www.nilf.no/om_nilf/Nyheter/2012/ gunnarsdottirrefsgaardnorway311_6th_world_water_forum.pdf

Hamelin, L., M. Wesnæs, H. Wenzel and B. M. Petersen (2010): "Life Cycle Assessment of Biogas from Separated slurry". Environmental Project No. 1329 2010, Danish Environmental Protection Agency.

HELCOM, 2007. HELCOM Baltic Sea action plan. Available at: http://www.helcom.fi/ BSAP/ActionPlan.

HELCOM (Helsinki Commission) (2009), Eutrophication in the Baltic Sea: An integrated thematic assessment of the effects of nutrient enrichment in the Baltic Sea Region - Executive Summary, Baltic Sea Environment Proceedings No. 115A, HELCOM, Helsinki, Finland.

Lukehurst, C. T., Frost, P., Al Sead, T., 2010. Utilisation of digestate from biogas plants as biofertiliser. Utilisation of digestate from biogas plants as biofertiliser. IEA Bio- 
energy. Available at: http://www.iea-biogas.net/_download/publi-task37/

Task37_Digestate_brochure9-2010.pdf

IIPCC. 2006 IPCC guidelines for national greenhouse gas inventories. IGES, Japan, 2006.

Smith, P., D. Martino, Z. Cai, D. Gwary, H. Janzen, P. Kumar, B. McCarl, S. Ogle, F.

O'Mara, C. Rice, B. Scholes, O. Sirotenko, 2007: Agriculture. In Climate Change 2007:

Mitigation. Contribution of Working Group III to the Fourth Assessment Report of the Intergovernmental Panel on Climate Change [B. Metz, O.R. Davidson, P.R. Bosch, R. Dave, L.A. Meyer (eds)], Cambridge University Press, Cambridge, United Kingdom and New York, NY, USA.

Snyder, C.S., T.W. Bruulsema, and T.L. Jensen. 2007. Greenhouse gas emissions from cropping systems and the influence of fertilizer management-a literature review. International Plant Nutrition Institute, Norcross, Georgia, U.S.A.

Iversen T. M., B. Hasler, P. N. Jensen, J. Waagepetersen, G. Rubæk, B. Jacobsen (2009): "Notat vedr. virkemidler og omkostninger til implementering af vandrammedirektivet". Danmarks Miljøundersøgelser, Aarhus Universitet, Det Jordbrugsvidenskabelige Fakultet, Aarhus Universitet, Fødevareøkonomisk Institut, Københavns Universitet.

Jacobsen B. H., B. Hasler, L. B. Hansen (2009): “Økonomisk Midtvejsevaluering af Vandmiljøplan III”. Available at: http://www.vmp3.dk/Files/Filer/ Gennemfoerelse/Evaluering/VMPIII-Oek-midtvejsrapport-final.pdf

Jensen, P. N., S. Boutrup, J. R. Fredshavn, L. M. Svendsen, G. Blicher-Mathiesen, P. Wiberg-Larsen, R. Bjerring, J. W. Hansen, K. E. Nielsen, T. Ellermann, L. Thorling and A. G. Holm (2012): “VANDMILJØ OG NATUR 201. NOVANA. Tilstand og udvikling - faglig sammenfatning". Videnskabelig rapport fra DCE - Nationalt Center for Miljø og Energi, nr. 36, 2012. Aarhus Universitet, DCE - Nationalt Center for Miljø og Energi.

Jóhannesson, T. (2010): “Agriculture in Iceland: Conditions and Characteristics”. Agricultural University of Iceland.

Jordbruksverket (2013). Stöd till landsbygden. http://www.jordbruksverket.se

King, D. M. 2005. Crunch time for water quality trading. Choices 20 (1): 71-6.

Kronvang B., H. E. Andersen, C. Børgesen, T. Dalgaard, S. E. Larsen, J. Bøgestrand, G. Blicher-Mathiasen (2008): "Effects of policy measures implemented in Denmark on nitrogen pollution of the aquatic environment". Environmental Science \& Policy, Volume 11, Issue 2, April 2008, Pages 144-152.

Kvakkestad, V., Nebell, I., og Rålm, P.K., 2012. En gjennomgang av virkemidler under Landbruks- og matdepartementet med betydning for økosystemtjenester. NILF notat 22. Oslo.

Kvakkestad, V., Vatn A., 2004. Virkemidler for multifunksjonelt landbruk - Avveiningen mellom transaksjonskostnader og presisjon. In Lindquist L. (ed.): Lantbrukets og landsbygdens framtida roller. TemaNord 2004:516. Copenhagen: Nordic Council of Ministers, pp. 123-132.

Lankoski, J., M. Ollikainen (2011): “Counterfactual approach for assessing agrienvironmental policy: The case of the Finnish water protection policy". Paper prepared for presentation at the EAAE 2011 Congress Change and Uncertainty Challenges for Agriculture, Food and Natural Resources August 30 to September 2, 2011 ETH Zurich, Zurich, Switzerland

Lankoski, J., M. Ollikainen, P. Uusitalo (2006): “No-till technology: benefits to farmers and the environment? Theoretical analysis and application to Finnish agriculture". European Review of Agricultural Economics. Vol. 33, no. 2, p. 193-221. 
Lantz, M, Svensson, M, Björnsson, L, Börjesson, P. The prospects for an expansion of biogas systems in Sweden--Incentives, barriers and potentials. Energy Policy 2007; 35 (3): 1830-1843.

Laukkanen, M., C. Nauges (2012): "Impact of agri-environmental policies on farming practices and nutrient loading". Contributed paper prepared for presentation at the 56th AARES annual conference, Fremantle, Western Australia, February 7-10.

Lehtonen, H., I. Barlund, S. Tattari, M. Hilden 2007a: “Combining dynamic economic analysis and environmental impact modelling: Addressing uncertainty and complexity of agricultural development". Environmental Modelling \& Software, vol. 22, no. 5 , p. $710-718$.

Lehtonen, H., J. Aakkula, P. Rikkonen (2005): “Alternative Agricultural Policy Scenarios, Sector Modelling and Indicators: A Sustainability Assessment". Journal of Sustainable Agriculture. Vol. 23, no. 4.

Lehtonen, H., J. Lankoski, K. Koikkalainen 2007b: “Economic and environmental performance of alternative policy measures to reduce nutrient surpluses in Finnish agriculture". Agricultural and Food Science, vol. 16, p. 421-440.

Lien G., Flaten, O., Jervell, A.M., Ebbesvik, M., Koesling, M. and Valle, P.S., 2006. Management and risk characteristics of part-time and full-time farmers in Norway. Review of Agricultural Economics. 28(1) pp. 111-131.

Miljøministeriet (2008): “Indsatsplan om kompenserende foranstaltninger som følge af midlertidig ophævelse af kravet om braklægning i 2008". Ministeriet for Fødevarer, Landbrug og Fiskeri. Available at: http://www.mst.dk/NR/rdonlyres/ 60C50A41-4C31-49E2-BBA3-1D2FCADCDA3F/57243/Brak_Indsatsplan1.pdf

Miljøministeriet (2008):"Midtvejsevaluering af Vandmiljøplan III: Afrapportering fra kommisorium for fosforafgift". Available at: http://www.vmp3.dk/Files/Filer/ Gennemfoerelse/Evaluering/Fosforafgiftnotat.pdf

Ministeriet for Fødevarer, Landbrug og Fiskeri (2013). Tilskudsguide for landbrug. http://2.naturerhverv.fvm.dk/

Ministeriet for Fødevarer, Landbrug og Fiskeri og Miljøministeriet (2008): “Afrapportering fra arbejdsgruppen om udredning af mulighederne for justering af afgrødenormsystemet med henblik på optimering af gødsknings- og miljøeffekt - "noget for noget"'. Report from working group consisting of representatives from Det Jordbrugsvidenskabelige Fakultet (Aarhus Universitet), Danmarks Miljøundersøgelser (Aarhus Universitet), Fødevareøkonomisk Institut (Københavns Universitet), Dansk Landbrugsrådgivning, Landscentret, Miljøstyrelsen (tidligere Skov- og Naturstyrelsen), Plantedirektoratet (formandskab og sekretariat). Available at: http:// www.mst.dk/NR/rdonlyres/60C50A41-4C31-49E2-BBA3-1D2FCADCDA3F/ 61974/FVM057_Nogetfornogetendeligafrapportering.pdf

Ministry for the Environment (2007): "Iceland's Climate Change Strategy". Available at: http://eng.umhverfisraduneyti.is/media/PDF_skrar/Stefnumorkun_i_loftslagsmalum _enlokagerd.pdfAakkula, J., M. Kuussaari, K. Rankinen, P. Ekholm, J. Heliölä, T. Hyvönen, L. Kitti and T. Salo (2011): "Follow-up Study on the Impacts of Agrienvironmental Measures in Finland". OECD Workshop on the Evaluation of Agrienvironmental Policies 20-22 June 2011. The Johann Heinrich von Thünen Institute, Bundesallee 50, 38116 Braunschweig, Germany

Ministry of Agriculture, Sweden (2010): The Rural Development Programme 20072013. For a living countryside and growth. http://www.government.se

Ministry of Environment, Sweden (2010): “Proposal for Sweden's National Implementation Plan for the Baltic Sea Action Plan". Available at: http://www.helcom.fi/ stc/files/BSAP/SE_NIP.pdf 
Ministry of Agriculture and Food (2011): “Meld. St. 9 (2011-2012). Landbruks- og matpolitikken, Velkommen til bords". http://www.regjeringen.no

Ministry of Food, Agriculture and Fisheries (2008): "The Danish Rural Development Programme 2007-2013".

Mohlin, K., 2012. Nitrogen taxes and greenhouse gas emissions from agriculture. University of Gothenburg.

Mosquera, J., J.M.G. Hol, C. Rappoldt, J. Dolfing, 2007. Precise soil management as a tool to reduce $\mathrm{CH} 4$ and $\mathrm{N} 2 \mathrm{O}$ emissions from agricultural soils. Report 28, Animal Sciences Group, Wageningen UR.

Mullins, 2009. Phosphorus, Agriculture \& the Environment. Virginia State University. (http://pubs.ext.vt.edu/424/424-029/424-029_pdf.pdf)

Swedish Environmental Protection Agency, 2009. Sveriges åtagande I Baltic Sea Action Plan Förslag till nationell åtgärdsplan. Rapport 5985. Naturvårdsverket, Stockholm.

NEFCO, 2008. Framework for a Nutrient Quota and Credits' Trading System for the Contracting Parties of HELCOM in order to reduce Eutrophication of the Baltic Sea. NEFCO, Helsinki. Available at: http://www.nefco.org/files/Nefco_BS\%20NTS_GSN Final\%20Report_20080229.pdf

Niemi, J., and J. Ahlsted eds.) (2012): "Finnish agriculture and rural industries 2012". MTT Economic Research, Agrifood Research Finland. Helsinki, Finland.

Nordic Energy Technology Perspective, 2013. Available at: http:// www.nordicenergy.org/wp-content/uploads/2012/03/Nordic-EnergyTechnology-Perspectives.pdf

Normander, B., Jensen, T.S., Henrichs, T., Sanderson, H. \& Pedersen, A.B. (red.) (2009): "Natur og Miljø 2009 - Del A: Danmarks miljø under globale udfordringer". Faglig rapport fra DMU nr. 750. Danmarks Miljøundersøgelser, Aarhus Universitet. OECD, 2001. Multifunctionality. Towards an analytical framework. Paris, OECD.

OECD (2008), Environmental Performance of Agriculture in OECD countries since 1990, Paris, France.

OECD (2011a (2011): “Agricultural Policy Monitoring and Evaluation 2011. OECD Countries and Emerging Economies". OECD Publishing.

OECD 2011b. A Green Growth Strategy for Food and Agriculture. Preliminary Report. OECD Publishing.

OECD, 2012a. Farmer behaviour, agricultural management and climate change. OECD Publishing, Paris.

OECD, 2012b. Water quality and agriculture. Meeting the policy challenge. OECD Publishing, Paris.

Proceedings of the Joint International Conference Communications de la Conférence Internationale Commune 17-19 décembre 2006, Alger

Refsgaard, K., M. Bechmann, AG. B. Blankenberg, S. Skøien, A. Veidal. (2010): “Kostnadseffektivitet for tiltak mot fosfortap fra jordbruksarealer i Østfold og Akershus". NILFrapport 2010-2.

Regeringen (2009a): "Aftale om Grøn Vækst". Available at: http://www.google.dk/ url?sa=t\&rct=j\&q=aftale $\% 20 \mathrm{om} \% 20 \mathrm{gr} \% \mathrm{C} 3 \% \mathrm{~B} 8 \mathrm{n} \% 20 \mathrm{v} \% \mathrm{C} 3 \% \mathrm{~A}$ kst $\&$ source=web \&cd=1\&ved=0CCgQFjAA\&url=http\%3A\%2F\%2Fwww.fvm.dk\%2FAdmin \%2FPubli c\%2FDWSDownload.aspx\%3FFile\%3D\%252FFiles\%252FFiler\%252FPublikatione r\%252FGrn_Vkst-aftale_final.pdf\&ei=kaD-UNm4L6aA4gTh14CIBg\&usg= AFQjCNEW0K5NJZSgyVd2i5PfR8d7PZDBvA 
Regeringen (2009b): “Grøn Vækst”. Available at: http://www.mim.dk/NR/rdonlyres/ D5E4FC9A-B3AC-4C9A-B819-C42300F23CCA/0/GROENVAEKST_2904rapporten.pdf

Regeringen (2010): “Aftale mellem Regeringen og Dansk Folkeparti om Grøn Vækst 2.0". Available at: http://www.mim.dk/NR/rdonlyres/89DD7552-E925-4CA08E5B-C5072D40D18D/0/GroenVaekst2_0.pdf

Ryan, R.L., Erickson, D.L., De Young, R., 2003. Farmers' motivations for adopting conservation practices along riparian zones in a mid-western agricultural watershed. Journal of Environmental Planning and Management 46, 19-37.

Rye, J.F., Storstad, O., 2002. Trender i norsk landbruk 2002 : Frekvensrapport. Norsk senter for bygdeforskning, Trondheim.

Salamon, S., 1985. Ethnic-communities and the structure of agriculture. Rural Sociology 50, 323-340.

Savchuk. 0. 2003. Resolving the Baltic Sea into seven subbasins: N and P budgets for 1991-1999. Journal of Marine Systems 56(1-2):1-15.

Schmutzler, A., Goulder, L.H., 1997. The choice between emission taxes and output taxes under

imperfect monitoring. J Environ Econ Manage 32(1):51-64

Schou et al. (2007): Virkemidler til realisering af målene i EU's vandrammedirektiv. DMU rapport nr. 625.

Siebert, R., Toogood, M., Knierim, A., 2006. Factors affecting European farmers' participation in biodiversity policies. Sociologia Ruralis 46, 318-340.

Smith, P., D. Martino, Z. Cai, D. Gwary, H. Janzen, P. Kumar, B. McCarl, S. Ogle, F. O’Mara, C. Rice, B. Scholes, O. Sirotenko (2007): Agriculture. In Climate Change 2007: Mitigation. Contribution of Working Group III to the Fourth Assessment Report of the Intergovernmental Panel on Climate Change [B. Metz, O.R. Davidson, P.R. Bosch, R. Dave, L.A. Meyer (eds)], Cambridge University Press, Cambridge, United Kingdom and New York, NY, USA.

Stolze,M., Piorr, A., Häring, A. \& Dabbert, S., 2000. The environmental impacts of organic farming in Europe. Organic Farming in Europe: Economics and Policy (volume 6), University of Hohenheim, 127 pp.

Vanslembrouck, I., Van Huylenbroeck, G., Verbeke, W., 2002. Determinants of the willingness of belgian farmers to participate in agri-environmental measures. Journal of Agricultural Economics 53, 489-511.

Vatn, A., 2002. Multifunctional Agriculture - some Consequences for International Trade Regimes. European Review of Agricultural Economics, 29(3):309-327

Vatn, 2005. Institutions and the Environment. Cheltenham, Edward Elgar.

Vatn, A., V. Kvakkestad, and P.K. Rørstad, 2002. Policies for Multifunctional Agriculture: The Trade-off between Transaction Costs and Precision. Report 23. Ås: Department of Economics and Social Sciences, Agricultural University of Norway.

VMP3: http://www.vmp3.dk/

Waagepetersen J., R. Grant, C. D. Børgesen and T. M. Iversen (2008a): “Midtvejsevaluering af Vandmiljøplan III". Rapport utarbeidet av det Jordbrukgsvitenskabelige Fakultet og Danmarks Mijøundersøgelser, Århus Universitet. Available at: http://www.vmp3.dk/Files/Filer/Gennemfoerelse/VMPIII_midtvejs_2008.pdf

Waagepetersen J., T. M. Iversen, B. Jacobsen (2008b): “Opdateret notat vedr. effekterne af en permanent nulstilling af udtagningsforpligtigelsen". Notat af Det Jordbrugsvidenskabelige Fakultet og Danmarks Miljøundersøgelser ved Aarhus Universitet og Fødevareøkonomisk Institut, Københavns Universitet. 
Willock, J., Deary, I.J., Edwards-Jones, G., Gibson, G.J., McGregor, M.J., Sutherland, A., Dent, J.B., Morgan, O. and Grieve, R., 1999. The Role of Attitudes and Objectives in Farmer Decision Making: Business and Environmentally-Oriented Behaviour in Scotland. Journal of Agricultural Economics 50(2), pp. 286-303.

Wirsenius, S., Hedenus, F., Mohlin, K., 2010. Greenhouse gas taxes on animal food products: rationale, tax scheme and climate mitigation effects. Climatic Change.

Wilson, G.A., 2001. From productivism to post-productivism ... and back again? Exploring the (un)changed natural and mental landscapes of European agriculture. Transactions of the Institute of British Geographers 26(1), pp. 77-102.

Øygarden, L., A. Grønlund, S. Skøien, K. Refsgaard, K. Krokann, K. Nordskog, M.

Bechmann, 2012. Evaluering av Regionale Miljøprogram (RMP) 2011. Vurdering av ordningen "Avrenning til vassdrag". Bioforsk rapport, vol. 7, nr. 12, 2012. 


\section{Sammendrag (norsk)}

Denne rapporten ser på hvordan virkemidler i jordbruket kan utformes for å fremme et bærekraftig jordbruk og grønn vekst. Erfaringer fra nordiske land med subsidier og andre økonomiske virkemidler har fått særlig fokus.

Avrenning av næringsstoffer fra jordbruket til elver, innsjøer og havområder kan skape store problemer med blant annet algeoppblomstring og eutrofiering. Kapittel 2 beskriver hvordan jordbruket bidrar til vannforurensing, klimagassutslipp og andre miljøutfordringer. Jordbruket både påvirker og er helt avhengig av økosystemet rundt seg. Vann, jord, gjødsel og andre innsatsmidler kombineres for å produsere private goder som korn og offentlige goder som kulturlandskap, matsikkerhet og forunrensing. Kapittel tre beskriver hvordan jordbruket produserer en kombinasjon av goder og hvordan dette påvirker utformingen av virkemidler. Det er utfordrende å lage virkemidler med formål å fremme et multifunsjonelt jordbruk, særlig med tanke på transaksjonskostnader vs. effekt. Bønder er motivert av flere ting enn økonomiske virkemidler, for eksempel vaner, kunnskap og normer.

Kapittel 4 presenterer virkemidler for å redusere miljøproblemer i jordbruket i Norden. De nordiske landene har mange av de samme målene jordbruket og legger vekt på kulturlandskap, biodiversitet, og vannforurensing. På Island har fokuset vært på bevaring og forbedring av sårbart jordsmonn.

Kapittel 5 presenterer et utvalg studier og evalueringer av virkemidler rettet mot jordbruk og miljø i nordiske land. I Finland er en meget stor andel av bøndene med i miljøprogrammet som blant annet skal redusere avrenning fra jordbruket. Likevel har ikke programmet hatt de ønskede effektene på vannforurensing og har bidratt til at mer jord har blitt dyrket og dermet økt avrenning av næringsstoffer til vann. Vurdering av alternative virkemidler og jordbrukspolitikk gir ingen klare svar på hva som mest effektivt kan redusere vannforurensing. Å gå bort fra produksjonsrettet støtte kan bidra til å redusere vannforurensing, men redusjon i totalt støttenivå gir ikke automatisk mindre forurensing.

I Sverige har virkemidlene bidratt til å redusere avrenning, men målene er ikke nådd. Tiltak som reduserer avrenning må iverksettes der det koster minst. Handel med kvoter for avrenning kan sørge for dette. Skatt 
på nitrogen i handelsgjødsel og skatt på kjøtt (forbrukerskatt) kan også bidra til å redusere både avrenning av næringstoffer og klimagassutslipp fra jordbruket, men er upopulære virkemidler.

Siden 1990 har Danmark redusert vannforurensing fra jordbruket ved å redusere bruk av gjødsel og øke gjødseleffektivitet. Gjennom implementeringen av Vanndirektivet må avrenning reduseres mer, noe som vil bli kostbart for jordbruket. Produksjon av biogass fra husdyrgjødsel og avfall fra produksjon har stort potensiale for å redusere utslipp av næringsstoffer, men har høye investeringskostnader.

Erfaringer fra Norge og Island viser hvordan bøndenes kunnskap og holdninger til miljøprobleme i jordbruket, i kombinasjon med de riktige tiltak og prosessene, kan redusere erosjon og annen forringelse av jorda.

I kapittel 6 blir erfaringene fra kapittel 5 brukt til å anbefale utforming av virkemidler som kan bidra til et mer miljøvennling jordbruk. En helhetling tilnærming er nødvendig for utforming av virkemidler som både skal forsterke jordbruksproduksjon og redusere forurensing. Riktige tiltak må rettes mot de rette mottakerne gjennom prosesser der alle aktører blir involvert. Bønders holdninger og kunnskap er med på å avgjøre virkningen av tiltak, ikke bare økonomiske insentiver.

Grønn vekst er avhengig av forskning, innovasjon, utdanning og prosesser der alle akøtrer er involvert. God agronomi bidrar til effektiv utnyttelse av næringsstoffene og økt produksjon uten å øke forurensingen. Økonomiske insentiv som avgifter og holdningskampanjer rettet mot forbrukere kan bidra til å redusere matavfall og kjøttkomsum, som kan bidra til å redusere klimagassutslipp fra jordbruket. Produksjon av biogass er også et lovende tiltak som kan bidra til grønn vekst for hele samfunnet. 


\section{Agriculture and the environment in the Nordic countries}

In the future, demand for agricultural products will increase. The agricultural sector must meet the increase in demand without compromising the natural resources of which it depends on and damage fragile ecosystems. Sustainable agricultural practices and green growth is necessary for this to happen and agricultural policy must facilitate such development. How agriculture contributes to water pollution has been in focus in the Nordic countries for many years. In many places, nutrient emissions have been successfully reduces, but targets are still not met. The implementation of the Water Framework Directive makes policies that facilitate reduction of nutrient runoff even more relevant than before. This report looks at experiences from the Nordic countries and makes suggestions for future policies for sustainable agriculture and green growth.

The report has been commissioned by the Nordic Council of Ministers. The study was carried out by the Norwegian Agricultural Economics Research Institute (NILF).

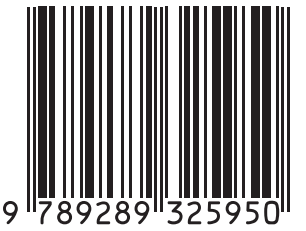

